\title{
Carboniferous barite-fluorite mineralization in the Late Devonian Kinsac Pluton, southern Nova Scotia
}

\author{
Daniel J. Kontak' ${ }^{1}$, Richard J. Horne ${ }^{1}$, Kevin Ansdell ${ }^{2}$, and Douglas A. Archibald ${ }^{3}$ \\ 'Nova Scotia Department of Natural Resources, P.O. Box 698, Halifax, NS B3J 2T9 \\ ${ }^{2}$ Department of Geological Sciences, University of Saskatchewan, \\ 114 Science Place, Saskatoon, SK S7N 5E2 \\ ${ }^{3}$ Department of Geological Sciences, Queen's University, Kingston, ON K7L 3N6
}

Date Received: August 31, 1998

Date Accepted: February 24, 1999

\begin{abstract}
Abundant barite \pm fluorite \pm quartz veins occur along the eastern margin of the Late Devonian Kinsac Pluton, a peraluminous granite that intruded metasedimentary rocks of the Meguma Group. The barite veins, striking $120^{\circ}$ with vertical dip, occur in areas of strongly fractured granite, but the veins are not deformed and may contain lenses of comminuted granite. The veins ( $\leq 0.6 \mathrm{~m}$ wide) are dominated by coarse, cloudy white barite euhedra with or without a late infill of euhedral clear quartz and pink to dark purple fluorite. ${ }^{40} \mathrm{Ar} /{ }^{39} \mathrm{Ar}$ step-wise heating of a K-feldspar megacryst in granite immediately adjacent to a barite vein indicates a $354 \mathrm{Ma}$ plateau age for the high-temperature gas fraction and a ca. $320 \mathrm{Ma}$ age for the lowtemperature gas fraction. The younger age is interpreted to record partial resetting of $\mathrm{K}$-feldspar due to interaction of the mineral with vein-forming fluids.

Fluid inclusions (aqueous, L-V types) hosted by vein fluorite have homogenization temperatures of $100^{\circ}$ to $130^{\circ} \mathrm{C}$. Last melting of ice indicates salinities of 24 to $28 \mathrm{wt}$. \% equivalent $\mathrm{NaCl}$, but low eutectic temperatures indicate that the fluids are mixed $\mathrm{NaCl}-\mathrm{CaCl}_{2}-\mathrm{FeCl}_{2}-\mathrm{MgCl}_{2}$ brines. Although fluorite-hosted fluid inclusions from the South Mountain Batholith have similar salinities, they homogenize at temperatures of $150^{\circ}$ to $160^{\circ} \mathrm{C}$. Stable isotopic studies of vein minerals indicate $\delta^{34} \mathrm{~S}_{\text {barite }}$ $=+13 \pm 2 \%$, $\delta^{18} \mathrm{O}_{\text {quart }}=+22 \%$ and $\delta \mathrm{D}$ for fluid inclusion extracts are -123 to $-165 \%$. The data are interpreted to indicate that: (1) sulphur was derived from dissolution of Windsor Group evaporites rather than from sulphides in basement rocks; (2) the $\delta^{18} \mathrm{O}_{\text {water }}$ of the veins was +8 to $+12 \%$ for $100^{\circ}$ to $150^{\circ} \mathrm{C}$, which is consistent with either a basinal or metamorphic fluid; (3) the fluids interacted with organic matter to generate the low $\delta \mathrm{D}$ values. Measured ${ }^{87} \mathrm{Sr} /{ }^{86} \mathrm{Sr}$ on barite $(0.7120 ; n=2)$ and fluorite $(0.7086)$ indicate that the fluids exchanged with a radiogenic source, either the Horton Group or the Meguma Group being the most likely reservoir.

Collectively the data indicate vein formation during the Early Carboniferous, when the study area was buried under ca. 2-3 $\mathrm{km}$ of Carboniferous strata which have subsequently been eroded. Basinal-type fluids were focused into zones of extension which opened as a result of high $\mathrm{P}_{\text {fluid, }}$ in concert with sinistral movement on NW-trending faults that crosscut the Meguma Terrane.
\end{abstract}

On trouve une abondance de filons de barytine \pm fluorite \pm quartz le long de la marge orientale du pluton du Dévonien supérieur de Kinsac, granite hyperalumineux qui s'est introduit dans des roches métasédimentaires du groupe de Meguma. Les filons de barytine, orientés selon un pendage vertical de $120^{\circ}$, se trouvent dans des zones de granite fortement fracturées, mais ils ne sont pas déformés et ils pourraient renfermer des lentilles de granite fragmenté. Les filons $(\leq 0,6 \mathrm{~m})$ sont dominés par la présence de barytine automorphe blanc trouble, grossière, avec ou sans remplissage tardif de quartz transparent automorphe et de fluorite rose à mauve foncé. Un réchauffement progressif ${ }^{40} \mathrm{Ar} /{ }^{39} \mathrm{Ar}$ d'un mégacristal de feldspath-K dans le granite immédiatement adjacent à un filon de barytine révèle que la fraction gazeuse à haute température a un âge plateau de $354 \mathrm{M}$.A. et que la fraction gazeuse à basse température est âgée de $320 \mathrm{M}$.A. L'âge le plus jeune est interprété comme l'enregistrement d'un rétablissement partiel de feldspath-K dû à l'interaction du minéral avec des fluides constitutifs de filons.

Des inclusions de fluides (aqueux de types L-V) contenues dans de la fluorite filonienne possèdent des températures d'homogénéisation de $100^{\circ}$ à $130^{\circ} \mathrm{C}$. La dernière fonte des glaces révèle des teneurs en sels équivalant à 24 à $28 \%$ en poids de $\mathrm{NaCl}$, mais les températures eutectiques basses révèlent que les fluides constituent des saumures mêlées de $\mathrm{NaCl}^{-C a C l} \mathrm{C}_{2}-$ $\mathrm{FeCl}_{2}-\mathrm{MgCl}_{2}$. Même si des inclusions de fluides contenues dans de la fluorite du batholithe du mont South affichent des salinités analogues, elles s'homogénéisent à des températures de $150^{\circ}$ à $160^{\circ} \mathrm{C}$. Des études des isotopes lourds des minéraux filoniens révèlent que $\delta^{34} \mathrm{~S}_{\text {barytine }}=+13 \pm 2 \%$, $\delta^{18} \mathrm{O}_{\text {quarz }}=+22 \%$ et que $\delta \mathrm{D}$ des extraits d'inclusions de fluides affichent -123 à $-165 \%$. Selon l'interprétation des chercheurs, ces données signifient : (1) que le soufre provient d'une dissolution d'évaporites du groupe de Windsor plutôt que de sulfures du socle rocheux; (2) que $\delta^{18} \mathrm{O}_{\text {deau }}$ des filons représentait +8 à $+12 \%$ à des températures de $100^{\circ}$ à $150^{\circ} \mathrm{C}$, ce qui correspond à un fluide métamorphique ou un fluide de bassin; et (3) que les fluides ont interagi avec la matière organique pour produire de faibles valeurs $\delta \mathrm{D}$. Le ${ }^{87} \mathrm{Sr} /{ }^{86} \mathrm{Sr}$ mesuré sur la barytine $(0,7120 ; n=2)$ et la fluorite $(0,7086)$ signale un échange de fluides avec une source radiogénique, soit les groupes de Horton ou de Meguma, qui constituent les réservoirs les plus vraisemblables.

Les données révèlent collectivement que les filons se sont formés au début du Carbonifère inférieur lorsque le secteur d'étude se trouvait enfoui sous environ deux à trois kilomètres de strates du Carbonifère, qui se sont subséquemment érodées. Les fluides de bassin ont été concentrés dans des zones d'extension qui se sont ouvertes sous l'influence de fluides $P$ à teneur élevée 
de concert avec un mouvement senestre sur les failles orientées vers le nord-ouest entrecoupant le terrane de Meguma.

\section{[Traduit par la rédaction]}

\section{INTRODUCTION}

Recent bedrock mapping of the Late Devonian Kinsac Pluton, part of a larger mapping project focusing on the metasedimentary rocks of the Meguma Group (Horne et al. 1997), led to the recognition of extensive barite-fluorite-quartz vein mineralization cutting the two-mica cordierite monzogranite. This paper presents field observations and geochemical studies that help to elucidate the nature and origin of these veins and their relevance to Carboniferous metallogeny within the Meguma Terrane. In southern Nova Scotia, barite mineralization occurs in many different settings [Fig. 1; see Felderhof (1978) for summary], consequently the timing and genesis of mineralization need not be directly linked to the immediate host rock, in this case the Kinsac Pluton. For example, barite occurs at Lake Fletcher as narrow veins in rocks of the Meguma Group (Fig. 1, Felderhof 1978), as a trace constituent in dolostone at the Gays River $\mathrm{Zn}-\mathrm{Pb}$ deposit (Kontak 1992), replacing sideritized Carboniferous limestone at the past-producing Walton deposit (Boyle 1972) and in Horton Group siltstone at the stillproductive Brookfield deposit (Felderhof 1978). Barite also occurs as a trace constituent of cockade- and comb-textured vein breccias cutting Meguma Group rocks at Little Tobeatic Lake (Corey and Graves 1996).

\section{REGIONAL GEOLOGICAL SETTING}

The Kinsac Pluton is a small (current exposure 10-12 $\mathrm{km}^{2}$ ) two-mica, cordierite-bearing monzogranite of Late Devonian age. It intruded Lower Paleozoic metasedimentary rocks of the Meguma Group that record Acadian deformation of 395-388 Ma (Keppie and Dallmeyer 1987; Hicks et al., 1999). A ${ }^{40} \mathrm{Ar} /{ }^{39} \mathrm{Ar}$ muscovite age of $363 \mathrm{Ma}$ has been documented for the Kinsac Pluton (Reynolds et al. 1981), however gravity modelling (Creasar 1996) suggests subsurface continuity of the pluton with the South Mountain and Musquodoboit batholiths, for which older ${ }^{40} \mathrm{Ar} /{ }^{39} \mathrm{Ar}$ mica dates (ca. $370 \mathrm{Ma}$ ) have been obtained (Reynolds et al. 1981; Keppie and Dallmeyer 1987; Clarke et al. 1993). The Kinsac Pluton is compositionally and texturally homogeneous and only a single monzogranitic phase is recognized, but late-stage aplite and pegmatite dykes occur, as well as quartz-tourmaline veins. The dyke rocks and various veins dip steeply and are oriented $\mathrm{WNW}$, whereas the joints may be of variable orientation (Fig. 2; Horne et al. 1997). Narrow shear zones of irregular density distribution cut the granite and have a steep, generally NW orientation with near horizontal slickenstriae (Fig. 2). The shear fractures are similar to structures cutting the South Mountain Batholith (Horne et al. 1992). Based on similar geochemistry and petrography, the Kinsac Pluton (Coolen 1974) is probably related genetically to the other peraluminous granites of the Meguma Terrane (Clarke et al. 1997).

\section{BARITE-FLUORITE-QUARTZ VEINS}

Veins dominated by barite $(>90 \%)$ occur throughout the central and eastern parts of the Kinsac Pluton and are exceptionally well exposed along recent road cuts (Figs. 2 and $3 a)$. The veins generally trend NS (125-140 ; Fig. 2), are steeply dipping, and have a maximum width of $0.6 \mathrm{~m}$, but most are 2 to $10 \mathrm{~cm}$ wide. The veins commonly bifurcate, and several may occur together over the length of an outcrop (i.e., 10's of m). Lack of outcrop does not allow assessment of the strike extension of the veins, but their exposed vertical extent is several metres, over which their width may vary by $50 \%$.

The barite veins invariably occur within narrow shear zones, although isolated areas of relatively massive and undeformed granite may occur within these highly strained zones. Slip lineations on the fracture surfaces indicate horizontal movement. The shear zones are typically characterized by narrow (centimetre-scale) central zones of microbreccia-cataclastite with wider (decimetre-scale) marginal zones of tightly spaced fracture cleavage. Barite veins typically occur within the central microbreccia-cataclastite zones (Fig. $3 \mathrm{~g}$ ). Where barite veins bifurcate, the shear zones do the same. The sheared nature of the granite adjacent to barite veins contrasts markedly with the massive and undeformed nature of the granite adjacent to aplite and pegmatite dykes and quartz-tourmaline veins, thereby suggesting markedly different modes of origin. The presence of lenses of finely comminuted granite in and adjacent to undeformed barite veins (Fig. $3 \mathrm{~g}$, h) indicates that this brittle deformation predated vein fill.

Vein fill is dominated by bladed barite euhedra, $4-10 \mathrm{~cm}$ in length, (Fig. 3a, b, d) generally oriented perpendicular to the vein walls. Absence of fibre-type growth indicates that veins formed in dilatant zones. Overall the veins are zoned such that later stage fluorite and euhedral quartz are concentrated between barite crystals in the vein cores (Fig. 3b, c, d), but fluorite may also line vein margins (Fig. 3f, g). Late veins parallel to the vein-wallrock contacts and cutting barite are lined with fine-grained, clear quartz euhedra. Most barite veins appear to have formed from a single dilation and infill event, but a minority of veins do indicate several dilational events. In a few places, veins consist of coarse barite euhedra bounded by massive, grey to blue grey laminated barite. At one locality (KP-96-5, Fig. 2), a near horizontal barite vein cross-cuts an earlier, steeply dipping barite vein.

Petrographic examination of the barite veins reveals an intergrowth of undeformed, bladed barite euhedra with late-stage infilling of pore space by quartz and zoned (purple to clear) fluorite (Fig. 3f, g). The fluorite may be overgrown by thin coatings of an Fe-oxide phase (Fig. 3f). Vein minerals are free of inclusions and undeformed. In contrast, wallrock minerals (e.g., feldspar, muscovite, quartz) are, respectively, fractured, kinked and display undulose extinction due to brittle deformation which pre-dated vein fill (Fig. $3 \mathrm{~g}, \mathrm{~h}$ ).

Fluorite mineralization may also occur as coatings $(\leq 1 \mathrm{~cm})$ of zoned, pink to dark purple fluorite euhedra decorating fracture surfaces in granite that have a similar orientation as the barite 
a
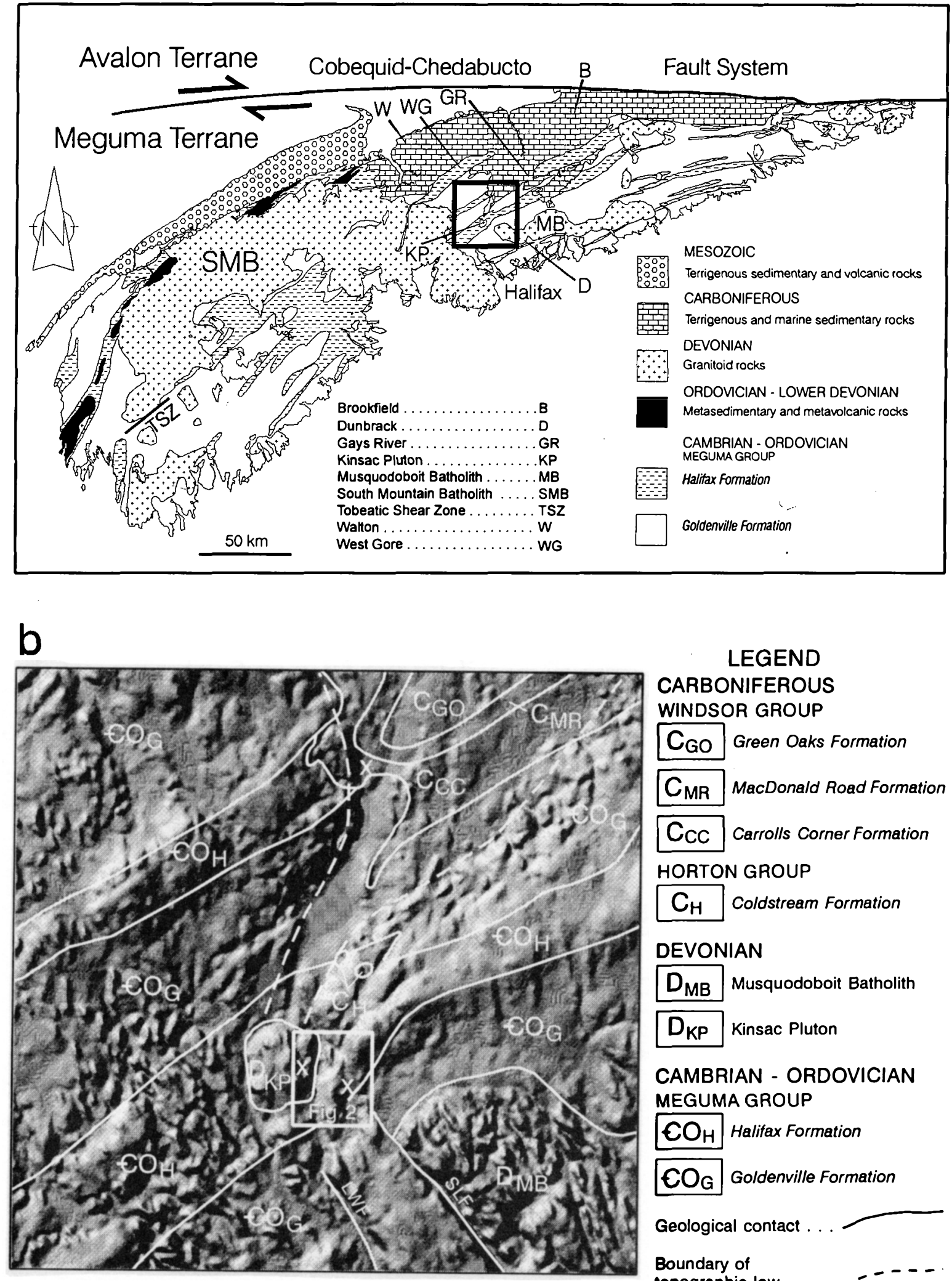

\section{LEGEND \\ CARBONIFEROUS WINDSOR GROUP \\ $\mathrm{C}_{\mathrm{GO}}$ Green Oaks Formation \\ $\mathrm{C}_{\mathrm{MR}}$ MacDonald Road Formation \\ C CC Carrolls Corner Formation}

HORTON GROUP

$\mathrm{C}_{\mathrm{H}}$ Coldstream Formation

\section{DEVONIAN}

$D_{\mathrm{MB}}$ Musquodoboit Batholith
$\mathrm{D}_{\mathrm{KP}}$ Kinsac Pluton

CAMBRIAN - ORDOVICIAN

MEGUMA GROUP

$\mathrm{CO}_{\mathrm{H}}$ Halifax Formation

$\mathrm{CO}_{\mathrm{G}}$ Goldenville Formation

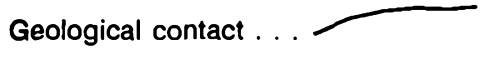

Boundary of

topographic low ........

Fig. 1. a) Generalized geological map of the Meguma Zone showing the location of the study area (box area) and the names and locations of places discussed in the text. b) Digital elevation model (DEM) map of the study area with the geology superimposed. Note the low lying area that extends from the Schubenacadie Basin towards the Kinsac Pluton $\left(D_{K}\right)$ which we suggest was infilled with Windsor Group rocks during the Carboniferous. The crosses (X) on the map indicate the location of barite occurrences in the Kinsac Pluton, the Meguma Group (Lake Fletcher occurrence) and one at the contact of the Carrolls Corner Formation and the Meguma Group, as observed in drill core (R.C. Boehner, personal communication, 1998). 

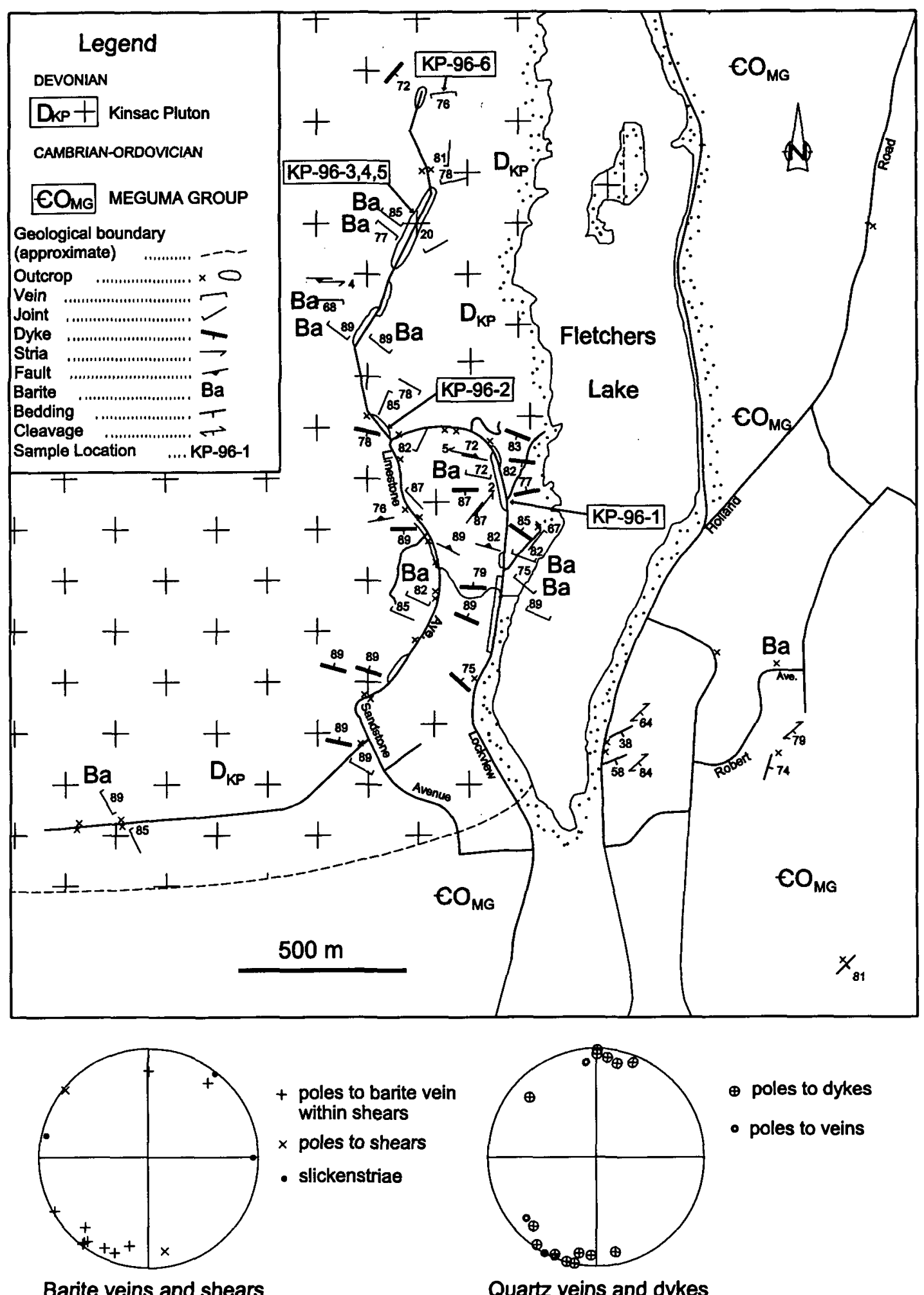

$\oplus$ poles to dykes

- poles to veins

Barite veins and shears

Quartz veins and dykes

Fig. 2. Geology map of the eastern part of the Kinsac Pluton showing the distribution of the barite veins and outcrops sampled in this study (e.g., KP-96-1). Diagrams at the bottom summarize the structural data for the barite veins, shears in the granite, slickenstriae, dykes and quartz-tourmaline veins. 
veins. We note in particular an abundance of such fluorite at locality KP-96-2 (Fig. 2). Trace amounts of barite, quartz and calcite intergrown with this fluorite suggests an origin similar to that of the barite-dominant veins. Fluorite veins are considered part of the same mineralizing event as the barite-rich veins.

\section{ANALYTICAL TECHNIQUES}

The major and trace element (Sr) chemistry of barite was determined using a JEOL Superprobe at Dalhousie University, using conditions given by Kontak and Smith (1993). The trace element chemistry of high-quality fluorite separates was determed by ICP-MS solution chemistry (Jenner et al. 1990). Two samples of fluorite were run in duplicate (KP-96-2, SMB$311 B$ ) and the results indicate excellent reproducibility of data. A suite of barite samples from the Walton deposit (Boyle 1972) and vein fluorite from the South Mountain Batholith were processed at the same time as the Kinsac samples for comparative purposes, as discussed below. A single, large sample of vein barite material (ca. 5-6 kg) was processed and analyzed for major and trace elements at the Technical University of Nova Scotia (TUNS) using wet chemical techniques.

A single ${ }^{40} \mathrm{Ar} /{ }^{39} \mathrm{Ar}$ age spectrum was determined for a sample of alkali feldspar at the geochron laboratory of Queen's University using an $8 \mathrm{~W}$ Lexel 3500 continuous argon-ion laser with a de-focused beam and procedures similar to those in Baksi et al. (1996). Dates and errors are calculated using formulae of Dalrymple et al. (1981), and the constants recommended by Steiger and Jager (1977). Errors shown in Table 1 and on the age spectrum (Fig. 4) represent analytical precision at $2 \sigma$, assuming that errors in the ages of the flux monitors are zero. This technique is suitable for comparing within-spectrum variation and determining which steps form a plateau (McDougall and Harrison 1988, p. 89). A conservative estimate of this error in the $\mathrm{J}$-value is $0.5 \%$ and can be added for inter-sample comparison. The dates are referenced to MAC-83 biotite at $24.1 \mathrm{Ma}(\mathrm{H}$. Sandeman, personal communication. 1998), whereas the age of MAC-83 biotite is referenced to TCR sanidine at $28.0 \mathrm{Ma}$ and GA 1550 biotite at $97.8 \mathrm{Ma}$ (Baksi et al. 1996).

Stable (S, O, D) and radiogenic ( $\mathrm{Sr}$ ) isotope analyses were performed at the University of Saskatchewan on hand-picked separates. Quartz separates were reacted with bromine pentafluoride followed by quantitative conversion to $\mathrm{CO}_{2}$ (Clayton and Mayeda 1963). Barite samples were heated in quartz tubing to about $1200^{\circ} \mathrm{C}$ to release sulphur as $\mathrm{SO}_{2}$. The gas was also passed over hot $\mathrm{CuO}$ to ensure conversion of all $\mathrm{SO}_{3}$ to $\mathrm{SO}_{2}$. Water is extracted from fluid inclusions in anhydrous minerals by slowly heating the samples until fusion occurs. The $\mathrm{H}_{2} \mathrm{O}$ is converted to $\mathrm{H}_{2}$ by reaction with hot $\left(850^{\circ} \mathrm{C}\right)$ uranium. Isotope ratios were determined using a VG model $602 \mathrm{E}(\mathrm{S})$, and Finnigan MAT 251(H) and Delta (O) mass spectrometers and are reported in the standard per mil (\%) notation relative to Canyon Diablo troilite (CDT) for sulphur and Vienna Standard Mean Ocean Water (V-SMOW) for oxygen and hydrogen. Analyses of laboratory standards indicate reproducibility $(1 \sigma)$ of $\delta^{34} \mathrm{~S}, \delta^{18} \mathrm{O}$ and $\delta \mathrm{D}$ using these techniques to be $\pm 0.3 \%$ o $\pm 0.2 \%$ and $\pm 3 \%$, respectively.
Barite and tourmaline were leached in $\mathrm{HCl}$ to remove surface contamination prior to dissolution in Savillex $\bigotimes$ beakers using $\mathrm{HCl}$ or $\mathrm{HF}-\mathrm{NO}_{3}$ mixtures, respectively. $\mathrm{Sr}$ was separated using standard cation-exchange procedures, and analyzed using a Finnigan MAT 261 mass spectrometer operated in the static mode. Sr isotope ratios were normalized to $\mathrm{a}^{86} \mathrm{Sr} /{ }^{88} \mathrm{Sr}$ value of 0.1194 , and the NBS987 Sr standard analyzed as part of this study yielded a value of $0.710225 \pm 0.000010$.

Fluid inclusions were studied in thick $(100 \mu \mathrm{m})$, doublypolished sections of vein barite-fluorite-quartz and thermometric analyses were done using a USGS heating-freezing stage calibrated with synthetic fluid inclusions. Gas analysis of crushed mineral separates (quartz, barite, fluorite) were determined using a quadrapole mass spectrometer at the University of Toronto using the procedures outlined in Bray and Spooner (1992).

\section{ANALYTiCAL RESULtS}

$$
{ }^{40} \mathrm{Ar} /{ }^{39} \text { Ar dating }
$$

A sample of alkali feldspar from immediately adjacent a 0.6 $\mathrm{m}$ wide barite-fluorite-quartz vein at locality KP-96-3 (Fig. 2) was analyzed using the ${ }^{40} \cdot \mathrm{Ar} /{ }^{39} \mathrm{Ar}$ step-wise heating technique and the age spectrum and data are given in Fig. 4 and Table 1, respectively. This sample was chosen because feldspars are prone to diffusive loss of argon even during low temperature (i.e., $150^{\circ} \mathrm{C}$ ) thermal events (McDougall and Harrison 1988), such as might have been caused by the movement of heated fluids associated with the formation of the veins in this study. Overall the age spectrum can be subdivided into two parts, a lowtemperature spectrum characterized by a monotonic increase in age with each step and a high-temperature concordant age spectrum; consequently the integrated age of $354 \mathrm{Ma}$ has no geological significance. The concordant part of the age spectrum indicates an age of $357 \pm 3 \mathrm{Ma}$, which records intracrystalline retention of argon as the feldspar passed through its blocking temperature. Given that ${ }^{40} \mathrm{Ar} /{ }^{39} \mathrm{Ar}$ dating of muscovite from the Kinsac Pluton gave an age of ca. 363 Ma (Reynolds et al. 1981), the slightly younger age for alkali feldspar may reflect the fact that this mineral has a lower blocking temperature than muscovite $\left(150^{\circ}\right.$ versus $\left.350^{\circ} \mathrm{C}\right)$ and, therefore, reflects primary cooling of the pluton (McDougall and Harrison 1988). The lowtemperature gas fraction, excluding the first step which has an anomalous old age due to excess argon, indicates an apparent age of ca. $320 \mathrm{Ma}$, which may record the time of an overprinting thermal disturbance such as vein formation.

\section{Bulk analysis of the vein}

A single sample of vein barite was pulverized and analyzed for a suite of elements (Table 2) in order to ascertain the presence of metallogenically important trace elements (e.g., Pb, $\mathrm{Ag}, \mathrm{Zn})$. The chemical analysis indicates that the sample contains by weight $83 \%$ barite, $12 \%$ quartz and $5 \%$ fluorite, which matches closely field observations on a large number of veins. In terms of the trace elements, the vein is slightly anomalous in $\mathrm{Ag}$ and $\mathrm{Au}$ compared to the Meguma Group and granites of the Meguma terrane (our unpublished data). 

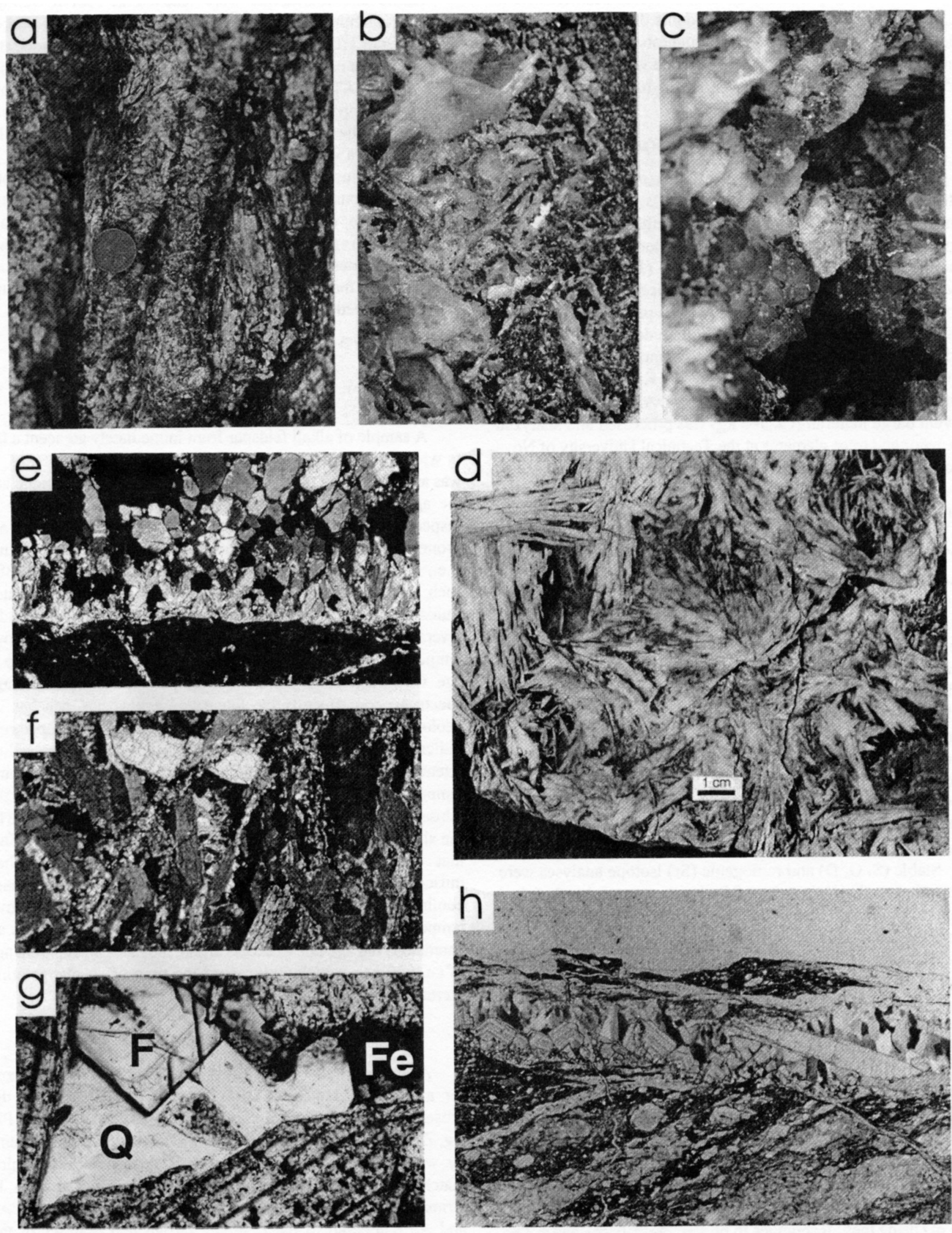
Table 1. Ar-Ar data for sample KP-96-3 K-feldspar from Kinsac Pluton marginal to barite vein.

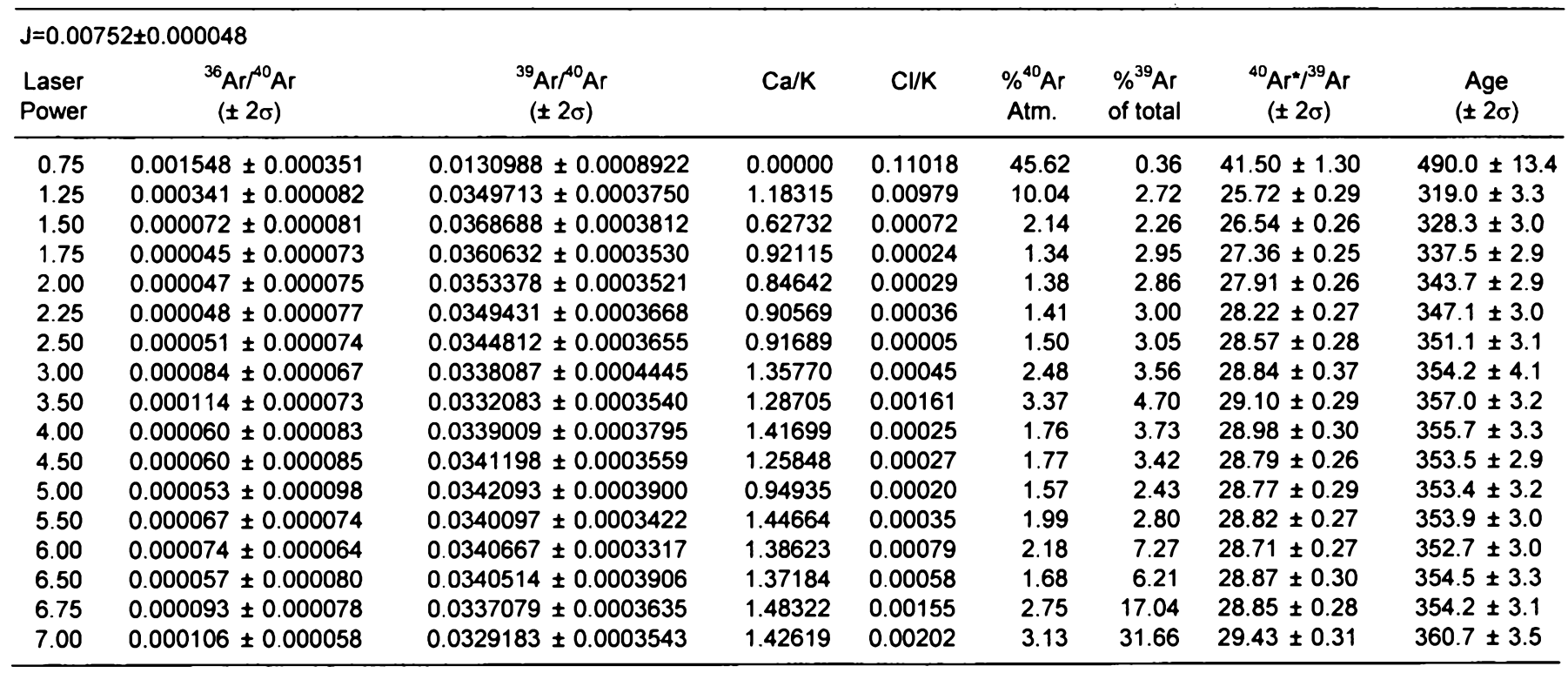

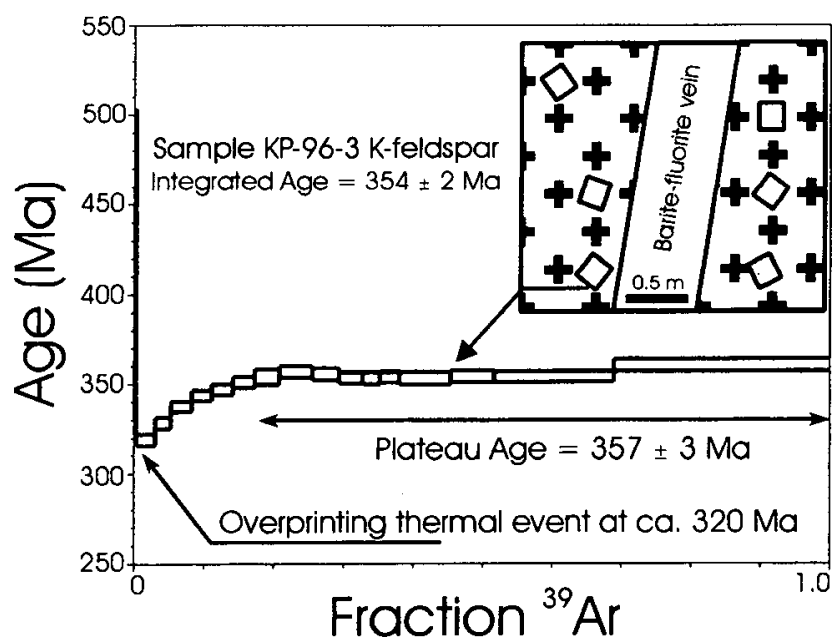

Table 2. Analysis of Barite vein sample, Kinsac Pluton

\begin{tabular}{lrlr}
\hline \multicolumn{2}{c}{$w t \%$} & \multicolumn{2}{c}{$p p m$} \\
\hline $\mathrm{Ba}$ & 46.91 & $\mathrm{Ag}$ & 8 \\
$\mathrm{SO}_{4}$ & 33.87 & $\mathrm{Au}$ & 0.024 \\
$\mathrm{SiO}_{2}$ & 14.55 & $\mathrm{~Pb}$ & 108 \\
$\mathrm{CaO}$ & 3.94 & $\mathrm{Zn}$ & 29 \\
$\mathrm{~F}$ & 2.24 & $\mathrm{Cu}$ & 7 \\
$\mathrm{Fe}$ & 0.21 & & \\
\hline
\end{tabular}

Fig. $4 .{ }^{40} \mathrm{Ar} /{ }^{39} \mathrm{Ar}$ age spectrum for alkali feldspar megacryst from biotitemuscovite cordierite monzogranite of the Kinsac Pluton (see Fig. 2 for sample location). Inset diagram illustrates the relationship between the vein and the dated sample. For this sample, the integrated age (Int. Age) is $354 \mathrm{Ma}$, the plateau age is $357 \mathrm{Ma}$, and the lowest age in the spectrum is $320 \mathrm{Ma}$, which is interpreted to reflect the time of vein formation, as discussed in the text.

Fig. 3. Photos of barite-quartz-fluorite veins in outcrop and thin section. (a) Barite vein in outcrop (locality KP-96-1, Fig. 1) showing the bladed nature of the barite euhedra. Note that the orientation of the fracture surface is NW and steeply dipping to the north. Coin diameter is $19 \mathrm{~mm}$. (b) Euhedral barite with dark purple fluorite (indicated by arrows) filling pore space between barite, thus indicating a late-stage paragenesis for fluorite. Width of photo ca. $2 \mathrm{~cm}$. (c) Late-stage quartz euhedra between barite. Width of photo ca. $1 \mathrm{~cm}$. (d) Slab of barite vein showing that crystals are up to $10 \mathrm{~cm}$ length and form radiating clusters. Note the lack of colloform, comb or banded textures. This sample formed from filling open space generated via a single episode of dilatancy. (e) Thin section photomicrograph illustrating the euhedral nature of the barite and their delicate, undeformed state. Black material is fluorite and barite at extinction. Long dimension of photo ca. $2.6 \mathrm{~mm}$. ( $\mathrm{f}$ ) Thin section photomicrograph showing zoned, clear and purple (grey in photo) fluorite filling open space between barite euhedra. The fluorite is overgrown by Fe oxide phase. Width of photo ca. $1.3 \mathrm{~mm}$. (g) Photomicrograph (crossed polars) showing undeformed barite-fluorite vein cross-cutting cataclastite (i.e., deformed granitic wallrock). Width of photo ca. $2 \mathrm{~cm}$. (h) Phtomicrograph (plane light) showing close up of area in upper right of Fig. $3 \mathrm{~g}$ to illustrate the vein fill of zoned fluorite and bladed barite. Note the presence of intensely deformed wallrock granite on both sides of the undeformed vein and the absence of fibre textures in the veins. Width of photo ca. $7 \mathrm{~mm}$. 


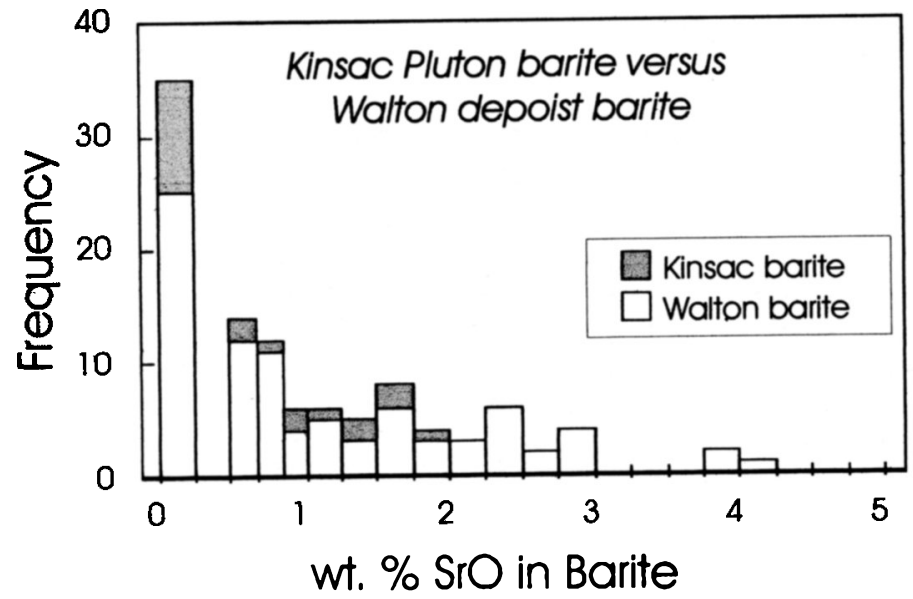

Fig. 5. Histogram summarizing the content of $\mathrm{SrO}$ in barite from Kinsac samples and Walton barite deposit., as determined by electron microprobe analysis (note limit of detection is ca. $0.2 \mathrm{wt}$. \%).

\section{Barite chemistry}

Barite from several vein samples $(n=4)$ was analyzed for $B a$, $\mathrm{S}$ and $\mathrm{Sr}$ and several different types of barite from the Walton deposit $(\mathrm{n}=8)$ were also analyzed for comparative purposes. All barite analyses are stoichiometric with respect to major elements (i.e., $\mathrm{BaSO}_{4}$ ), whereas results for $\mathrm{SrO}$ vary from below detection limit (ca. $0.2 \mathrm{wt} . \%$ ) to about $2 \mathrm{wt}$. \%, which is somewhat similar to the spread in $\mathrm{SrO}$ for Walton barite (Fig. 5). Within individual samples there is a large range in $\mathrm{Sr}$ content; thus, it is apparent that the variation is not vein specific, but common to all veins. Similar chemical variation of $\mathrm{Sr}$ in natural barite has been related to sector or intrasector zonation (Rock and Paquette 1998). We also note that values of 1 to $2.3 \mathrm{wt}$ \% $\mathrm{SrO}$ have been reported for barite from the Lake Ainslie area, Cape Breton Island (Macdonald 1999). Thus, the Kinsac barite is not exceptional in its enrichment or depletion of strontium.

\section{Fluorite Chemistry}

Late-stage fluorite intergrown with barite (KP-96-5) and coating fractures in granite (KP-96-2) was analyzed, as well as fluorite in quartz veins hosted by leucomonzogranite of the South Mountain Batholith (SMB); the data are summarized in Table 3 and displayed on chondrite-normalized plots in Fig. 6. The following points are noted: (1) samples of different coloured fluorite from locality KP-96-2 (2, 2.1B, 2.2C) have similar trace element chemistry, except for $\mathrm{Ba}$ and $\mathrm{Sr}$, which are related to microinclusions of barite. Thus, the colour variation in fluorite cannot be related to any of the trace elements determined in this study; (2) levels of $\mathrm{Rb}, \mathrm{Sr}, \mathrm{Li}$ and $\mathrm{Ba}$ are generally low in all samples and compare to levels reported in hydrothermal fluorite from the Lake Ainslie area of Cape Breton Island (Macdonald 1999), but contrasts with the trace element chemistry of fluorite associated with carbonatite (e.g., Palmer and Williams-Jones 1996). Elevated $\mathrm{Ba}$ in sample KP-96-5.1 (10376 ppm) relates to microinclusions of barite in the separate, as confirmed from petrography; (3) the low levels of $\mathrm{Zr}$ preclude contamination from zircon that might influence the REE data (see below); (4) the Kinsac fluorite is enriched relative to that of the SMB in $\mathrm{Sr}$, $\mathrm{Y}$ and $\mathrm{Ba}$, although the $\mathrm{Ba}$ and some $\mathrm{Sr}$ relates to barite
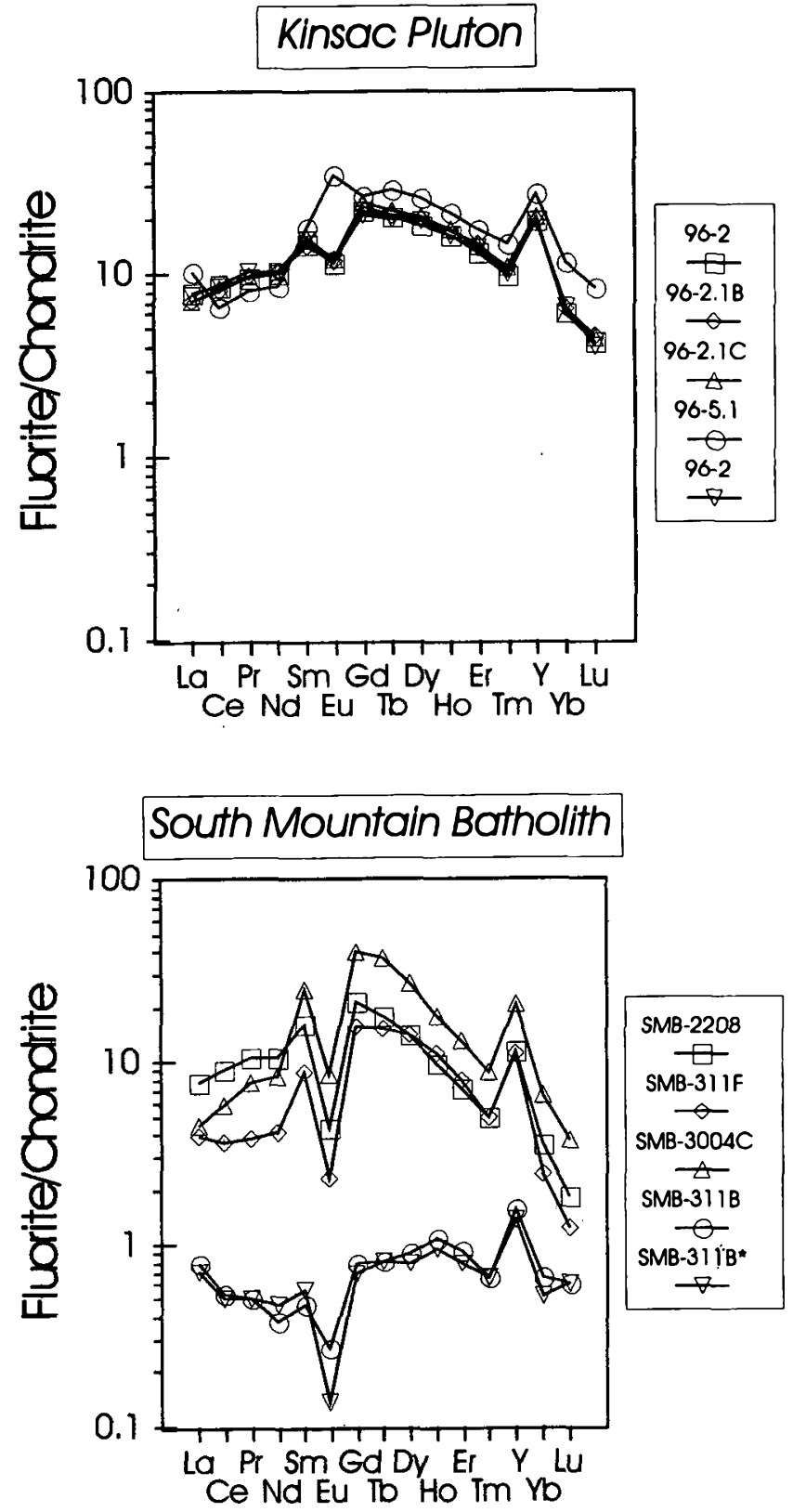

Fig. 6. Chondrite-normalized REE plots for fluorite from the Kinsac barite-fluorite veins and for quartz-fluorite veins in the South Mountain Batholith which were also analyzed in this study. Note that for the Kinsac fluorites there is a single sample (96-5.1) that has a positive $\mathrm{Eu}$ and negative Ce anomaly. Note also that sample KP-96-2 and SMB$311 \mathrm{~B}$ have been analyzed in duplicate.

inclusions; and (5) fluorite from a barite vein (KP-96-5.1) is notably enriched in $\mathrm{Pb}$ compared to the fracture coating fluorite (KP-96-2).

The rare-earth element (REE) chemistry of Kinsac fluorite (Fig. 6a) is generally similar for the two localities (i.e., KP-96-2 and 96-5). However, there is a slight overall enrichment in sample KP- 96-5.1, which is also characterized by a positive Eu anomaly, whereas the other fluorite samples analysed have negative $\mathrm{Eu}$ anomalies. Interestingly, the only sample with a positive Eu anomaly is also characterized by a slight negative $\mathrm{Ce}$ anomaly, both of which are a function of oxygen fugacity (Henderson 1984). In general, all the fluorites are slightly 
Table 3. Fluorite trace element geochemistry for samples from Kinsac Pluton and South Mountain Bahtolith

\begin{tabular}{|c|c|c|c|c|c|c|c|c|c|c|c|}
\hline \multirow{2}{*}{\multicolumn{2}{|c|}{$\begin{array}{l}\text { Detection } \\
\text { Limit }\end{array}$}} & \multicolumn{5}{|c|}{ Kinsac Pluton } & \multicolumn{5}{|c|}{ South Mountain Batholith } \\
\hline & & $96-2$ & $96-2.1 \mathrm{~B}$ & $96-2.1 \mathrm{C}$ & $96-5.1$ & 96-2(D) & 2208 & $311 \mathrm{~F}$ & 3004 & 3111B & $3111 B(D)$ \\
\hline $\mathrm{Li}$ & 0.58 & 0.54 & nd & nd & nd & nd & nd & nd & nd & 0.89 & 0.72 \\
\hline $\mathbf{R b}$ & 0.06 & 0.71 & 0.29 & 0.25 & 0.63 & 1.11 & 0.45 & 3.44 & 0.60 & 0.86 & 0.95 \\
\hline $\mathrm{Sr}$ & 0.16 & 69.76 & 49.54 & 38.55 & 203.95 & 66.12 & 34.60 & 13.50 & 29.80 & 12.80 & 11.00 \\
\hline Y & 0.01 & 135.68 & 135.83 & 140.99 & 189.67 & 134.10 & 78.30 & 77.10 & 143.40 & 10.90 & 9.50 \\
\hline $\mathrm{Zr}$ & 0.02 & 2.76 & 0.86 & 0.90 & 3.93 & 1.16 & 0.70 & 1.00 & 2.00 & 1.50 & 1.20 \\
\hline Nb & 0.00 & 0.06 & 0.02 & 0.02 & 0.06 & 0.07 & 0.03 & 0.03 & 0.03 & 0.03 & 0.03 \\
\hline Mo & 0.05 & nd & nd & nd & 3.43 & nd & 0.05 & 0.05 & 0.09 & nd & nd \\
\hline Cs & 0.02 & 0.12 & 0.10 & 0.10 & 0.86 & 0.19 & 0.05 & 0.12 & 0.03 & 0.10 & 0.09 \\
\hline $\mathrm{Ba}$ & 0.15 & 66.26 & 351.58 & 196.12 & 10376.99 & 88.01 & 0.70 & 2.70 & 1.60 & 1.40 & 1.30 \\
\hline $\mathrm{Hf}$ & 0.02 & 0.16 & 0.05 & 0.10 & 0.29 & 0.10 & 0.08 & 0.05 & 0.12 & 0.10 & 0.08 \\
\hline $\mathrm{Ta}$ & 0.00 & 0.02 & 0.01 & 0.01 & 0.12 & 0.02 & 0.02 & 0.01 & 0.02 & nd & nd \\
\hline TI & 0.02 & 0.07 & nd & nd & 1.75 & 0.09 & nd & nd & nd & nd & nd \\
\hline $\mathrm{Pb}$ & 0.11 & 22.77 & 4.34 & 3.95 & 531.96 & 25.31 & 7.60 & 0.20 & 0.70 & 0.07 & 0.07 \\
\hline $\mathrm{Bi}$ & 0.01 & 0.04 & 0.03 & 0.03 & 0.08 & 0.04 & nd & 0.09 & nd & nd & nd \\
\hline Th & 0.01 & 0.04 & 0.02 & 0.03 & 0.06 & 0.04 & 0.18 & 0.27 & 0.21 & 0.22 & 0.23 \\
\hline$U$ & 0.01 & 0.40 & 0.14 & 0.14 & 4.66 & 0.56 & nd & 0.13 & 0.14 & 0.11 & 0.12 \\
\hline La & 0.00 & 2.51 & 2.27 & 2.27 & 3.29 & 2.44 & 2.47 & 1.25 & 1.41 & 0.25 & 0.23 \\
\hline $\mathrm{Ce}$ & 0.01 & 7.08 & 6.68 & 6.87 & 5.46 & 7.19 & 7.35 & 2.94 & 4.70 & 0.44 & 0.42 \\
\hline $\operatorname{Pr}$ & 0.00 & 1.13 & 1.14 & 1.16 & 0.97 & 1.21 & 1.24 & 0.45 & 0.91 & 0.06 & 0.06 \\
\hline $\mathrm{Nd}$ & 0.02 & 6.15 & 6.22 & 6.20 & 5.20 & 6.32 & 6.37 & 2.49 & 5.09 & 0.23 & 0.28 \\
\hline $\mathrm{Sm}$ & 0.02 & 2.81 & 2.80 & 3.06 & 3.50 & 2.98 & 3.11 & 1.71 & 4.82 & 0.09 & 0.11 \\
\hline $\mathrm{Eu}$ & 0.01 & 0.83 & 0.85 & 0.88 & 2.52 & 0.87 & 0.32 & 0.17 & 0.63 & 0.02 & 0.01 \\
\hline Gd & 0.01 & 5.88 & 6.14 & 6.46 & 7.00 & 5.60 & 5.54 & 4.08 & 10.41 & 0.21 & 0.18 \\
\hline$T b$ & 0.00 & 1.01 & 1.04 & 1.11 & 1.45 & 0.99 & 0.89 & 0.75 & 1.82 & 0.04 & 0.04 \\
\hline Dy & 0.01 & 6.08 & 6.59 & 6.70 & 8.47 & 6.43 & 4.64 & 4.60 & 8.98 & 3.00 & 0.26 \\
\hline Ho & 0.00 & 1.19 & 1.26 & 1.29 & 1.59 & 1.19 & 0.72 & 0.83 & 1.30 & 0.08 & 0.07 \\
\hline Er & 0.01 & 2.86 & 3.18 & 3.06 & 3.79 & 2.99 & 1.54 & 1.71 & 2.84 & 0.20 & 0.17 \\
\hline $\mathrm{Tm}$ & 0.00 & 0.30 & 0.32 & 0.33 & 0.45 & 0.31 & 0.15 & 0.15 & 0.27 & 0.03 & 0.02 \\
\hline Yb & 0.02 & 1.28 & 1.36 & 1.25 & 2.46 & 1.38 & 0.74 & 0.51 & 1.39 & 0.14 & 0.11 \\
\hline Lu & 0.01 & 0.14 & 0.15 & 0.15 & 0.28 & 0.13 & 0.06 & 0.04 & 0.12 & 0.02 & 0.02 \\
\hline
\end{tabular}

Notes: Analyses labelled with (D) are duplicates; "nd" indicates element not detected

enriched in the HREE, with concave downwards and fractionated HREE patterns. In Fig. 6, $\mathrm{Y}$ is plotted with the HREE as it has been noted that fractionation between $Y$ and the HREE may occur (Strong et al. 1984). However, in this case there appears to be no change in the degree of $Y$ enrichment relative to the HREE, which suggests a single influx of fluid rather than repeated injection and evolution (i.e., enrichment/depletion of REE) of the fluid, as Strong et al. (1984) noted for zoned fluorite from the St. Lawrence fluorspar district, Newfoundland.

The Kinsac fluorite data are contrasted with a new data set from the SMB (Fig. 6b) and the following points are noted: (1) Kinsac samples are enriched in $\sum$ REE and have more uniform totals; (2) the SMB samples generally have more fractionated patterns; (3) the SMB samples are characterized by larger negative Eu anomalies, which reflect either (i) depletion of $\mathrm{Eu}$ in the vein-forming fluid, such as would occur if feldspar fractionated in the source reservoir (i.e., felsic magma), or (ii) dominance of $\mathrm{Eu}^{2+}$, which would exclude it from the fluorite structure because of its large radius compared to $\mathrm{Ca}^{2+}$ (Clark 1984). It is also possible that both of these mechanisms were important in establishing the degree of the Eu anomaly, which is uniformly developed in all samples. The behaviour of $Y$ in the
SMB fluorite samples is similar to that in the Kinsac fluorite samples.

\section{Fluid inclusions}

\section{Petrography}

Fluid inclusions of suitable size $(\geq 3-5 \mu \mathrm{m})$ occur in both barite and fluorite, but quartz is devoid of such fluid inclusions. However, the fluid inclusions in barite, despite being abundant, are not suitable for study because of their highly irregular L:V ratios and shapes which reflect post-entrapment changes (i.e., leaking and necking; Fig. 7a, b, c). Thus, thermometric work was restricted to inclusions hosted by fluorite, although both quartz and barite were also analyzed for their gas chemistry (see below).

Fluorite contains two phase, L-V aqueous inclusions (Fig. $7 \mathrm{e}, \mathrm{f}, \mathrm{g}$ ) that occur both as isolated inclusions and along planar arrays. Monophase inclusions are also present (Fig. 7d), but some of these may have formed from necking as they do not form isolated populations and inclusions with highly variable $\mathrm{L}: \mathrm{V}$ ratios commonly occur in close proximity, whereas others may relate to entrapment of later fluids. Samples were examined under UV light to check for the presence of liquid petroleum, but none was found. The two-phase L-V inclusions are 

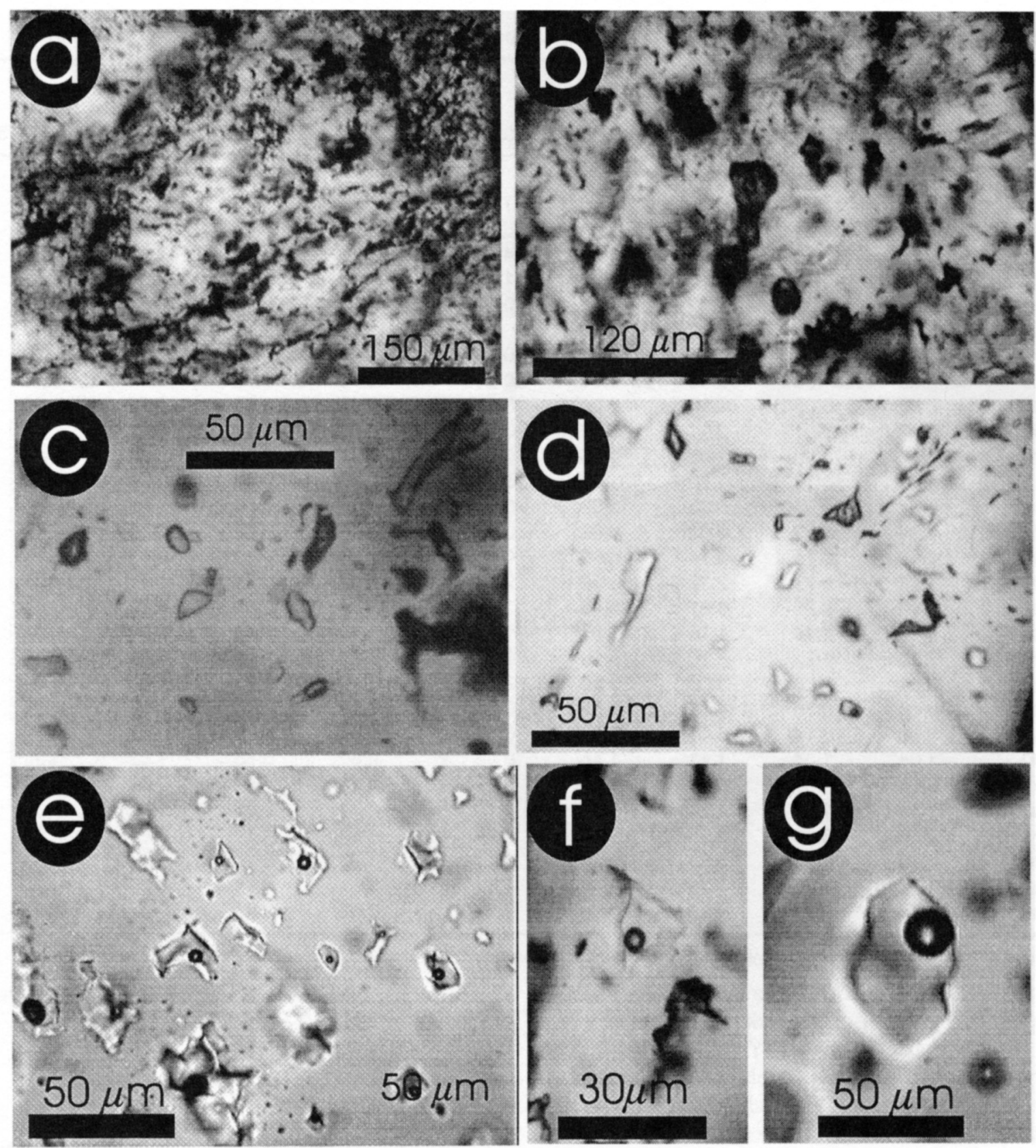

Fig. 7. Photomicrographs of aqueous fluid inclusions in vein barite $(\mathrm{a}, \mathrm{b}, \mathrm{c})$ and fluorite $(\mathrm{d}, \mathrm{e} f, \mathrm{~g})$ from the Kinsac Pluton. All inclusions in fluorite have 23 wt. \% equiv. $\mathrm{NaCl}$ salinties. (a, b) Barite inundated with fluid inclusions of variable shapes and $\mathrm{L}: \mathrm{V}$ ratios with monophase types dominant. (c) Area of monophase liquid and vapor-rich inclusions in barite that show evidence of necking. (d) Inclusions with irregular shapes and variable $\mathrm{L}: \mathrm{V}$ ratios resulting from post-entrapment modifications. (e) Group of two phase, equant to elongate inclusions of ca. $30 \mu \mathrm{m}$ length with uniform $\mathrm{L}: \mathrm{V}$ ratios that homogenize in the $127-132^{\circ} \mathrm{C}$ range. Inclusions are all at different focal depth and hence appear fuzzy. (f) Isolated, equant-shaped fluid inclusion in area of monophase inclusions. The tapered edges of the inclusion probably relate to post-entrapment necking. (g) Isolated, rectangular inclusion of $65 \mu \mathrm{m}$ length that homogenized at $130^{\circ} \mathrm{C}$.

conservatively interpreted as secondary because they cannot be related to growth planes within the fluorite host. Inclusion shapes vary from equant to irregular and many are elongate (aspect ratios of 10-50:1). Most importantly, however, the $\mathrm{L}: \mathrm{V}$ ratios are constant within fluid inclusion populations, which indicate a similar origin for the inclusions (Fig. 7e). Two samples (DK-85100,103 ) of fluorite from quartz-fluorite veins in the SMB were also studied to provide comparative data to the Kinsac fluorite. Abundant, two-phase L-V inclusions of equant shape occur and are dominated by the liquid phase. However, in one sample (DK85-100) the L:V ratios are very inconsistent, possibly suggesting post-entrapment changes (e.g., necking). The SMB fluid inclusions differ from those in Kinsac fluorite by having a larger $\mathrm{V}$ phase, from which a higher homogenization temperature can be inferred.

\section{Microthermometry-}

Freezing runs were made on inclusions in vein fluorite only, 

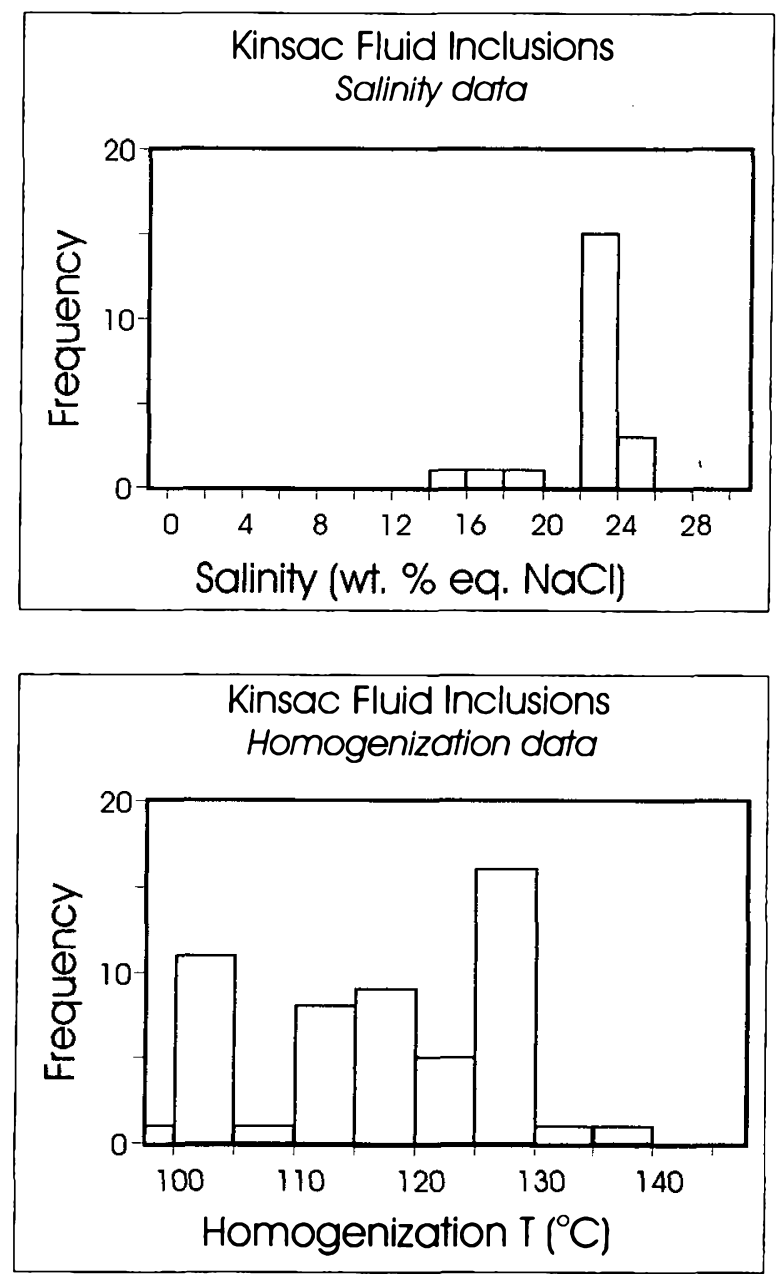
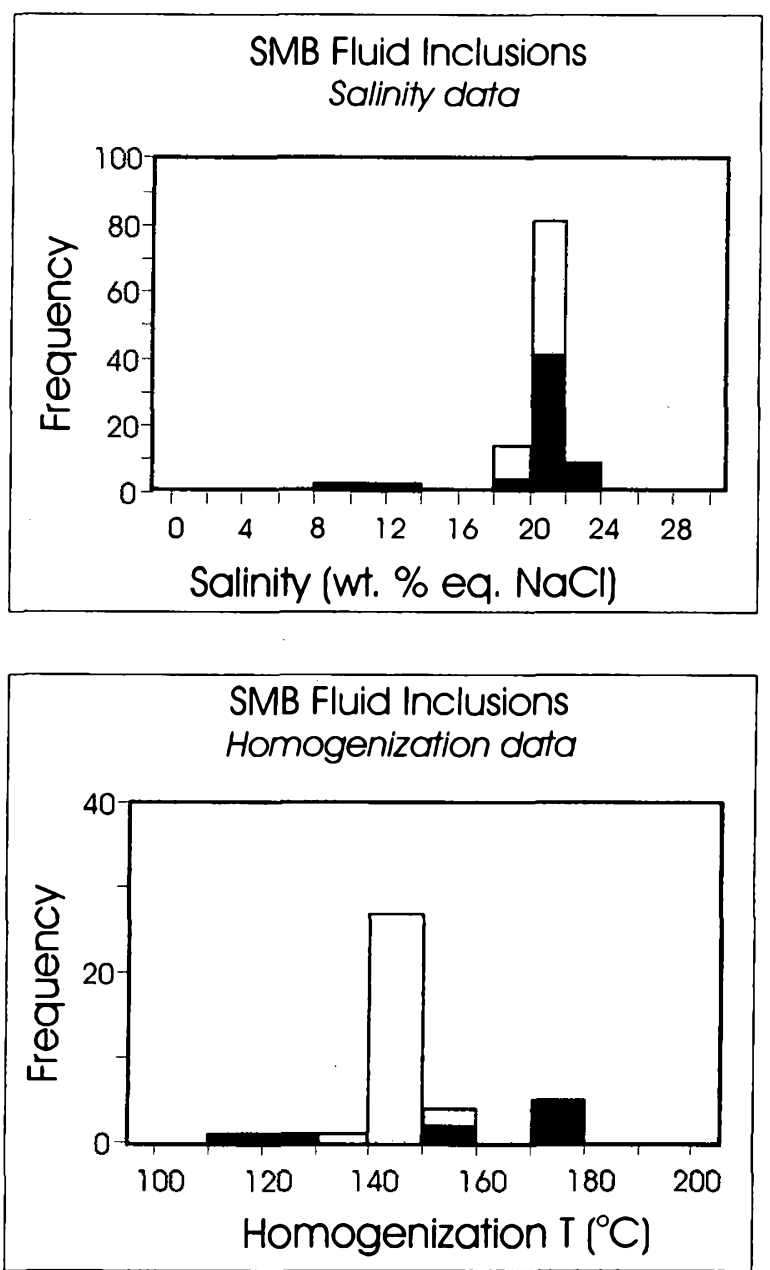

Fig. 8. Histograms summarizing results of thermometric data obtained on two phase L-V aqueous inclusions hosted by fluorite from Kinsac baritefluorite veins and two quartz-fluorite veins in the South Mountain Batholith (SMB).

as it was not possible to prepare suitable material from the fracture coating fluorite. The following observations were noted: (1) many inclusions did not freeze until $-70^{\circ}$ to $-85^{\circ} \mathrm{C}$ and in some cases some inclusions did not freeze at all, despite being cooled to $-190^{\circ} \mathrm{C}$ or being kept at $-100^{\circ} \mathrm{C}$ for $10-20$ minutes; (2) upon warming it was common for the vapor bubble to gradually collapse to the point where it was not visible until melting began; (3) a grainy texture developed between $-55^{\circ}$ and $-45^{\circ} \mathrm{C}$ and first melting occurred between $-35^{\circ}$ to $-32^{\circ} \mathrm{C}$, but most melting occurred in the $-25^{\circ}$ to $-21^{\circ} \mathrm{C}$ range. In an isolated inclusion first melting occurred around $-42^{\circ} \mathrm{C}$; (4) final melting of hydrohalite occurred between $-23^{\circ}$ and $-21^{\circ} \mathrm{C}$, with ice the last phase to melt at $-23^{\circ}$ to $-12^{\circ} \mathrm{C}$, but the majority of inclusions had last melting of ice at $-21.7^{\circ}$ to $-20^{\circ} \mathrm{C}$; and (5) in two inclusions hydrohalite was the last phase to melt at temperatures of $-9^{\circ}$ and $-17.5^{\circ} \mathrm{C}$. These melting relationships indicate that the fluids are high salinity (about 23 wt. \% eq. $\mathrm{NaCl}$; Fig. 8) and that small amounts of other cations are present in solution $\left(\mathrm{FeCl}_{2}, \mathrm{CaCl}_{2}, \mathrm{MgCl}_{2}\right)$, but generally the bulk composition of the fluid is close to the eutectic in the $\mathrm{H}_{2} \mathrm{O}-\mathrm{NaCl}$ system (Roedder 1984). The presence of a small number of inclusions of lower salinity (i.e., 16 to 20 wt. \% eq. $\mathrm{NaCl}$ ) might suggest dilution of the dominant fluid with a volumetrically smaller amount of lower salinity fluid.
Freezing runs on the SMB fluorites were very similar in terms of their temperatures for first and last melting. The most notable difference was in sample DK-85-103 where melting of hydrohalite occurred between $1^{\circ}$ and $3^{\circ} \mathrm{C}$ lower (i.e., $-23^{\circ}$ to $25^{\circ} \mathrm{C}$ ) than in the Kinsac samples. This behaviour suggests a slightly different bulk composition for the fluids. The salinity of the SMB fluorite inclusions (Fig. 8) is slightly lower than for the Kinsac samples, at 20 to $24 \mathrm{wt}$ \% eq. $\mathrm{NaCl}$, but with the majority at 20 to 22 wt. \% eq. $\mathrm{NaCl}$ (versus 24 to 28 wt. \% for Kinsac samples).

Heating runs of Kinsac inclusions indicate homogenization temperatures $\left(T_{h}\right)$ between $98^{\circ}$ and $142^{\circ} \mathrm{C}$, with most data in the $105^{\circ}$ to $130^{\circ} \mathrm{C}$ range (Fig. 8). Given that variable L:V ratios may occur and obvious cases of necking were noted, $T_{h}$ were only recorded for groups of inclusions with similar L:V ratios and in such cases uniform $T_{h}$ values were recorded (i.e., $\pm 1^{\circ} \mathrm{C}$ ). Thus, the range in $T_{h}$ reflects trapping of fluids of varying temperature. Many of the inclusions did not nucleate a vapor bubble upon cooling after homogenization, despite being left for several months. Homogenization temperatures for the SMB fluorites (Fig. 8) are ca. $150^{\circ} \mathrm{C}$ for sample DK-85-103 and $120^{\circ}$ to $180^{\circ} \mathrm{C}$ for DK-85-100, but the data for this latter sample are treated cautiously given the possibility of necking. Thus, the $T_{h}$ data for 


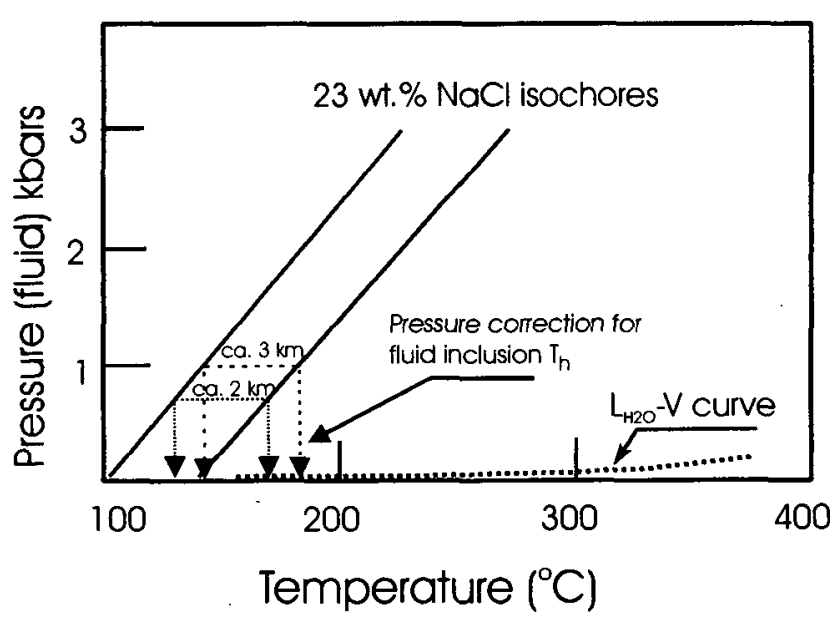

Fig. 9. Temperature-Pressure diagram showing the isochore for fluid of 23 wt. \% eq. $\mathrm{NaCl}$ with homogenization temperature of $120^{\circ} \mathrm{C}$. Isochore calculated with FLINCOR (Brown 1989), which uses the equations of Brown and Lamb (1989).

SMB fluorites are distinctly higher than the $T_{h}$ data for Kinsac fluorites.

Using the $T_{h}$ and salinity data (Fig. 9) isochores originating at $T_{h}$ of $100^{\circ}$ and $130^{\circ} \mathrm{C}$ were calculated for $23 \mathrm{wt} . \% \mathrm{NaCl}$ solutions. Geology constrains the present erosional surface to have been at or near the earth's surface during deposition of the Visean Windsor Group, but there are poor constraints on the stratigraphic thickness at the time of mineralization. As discussed below, Ryan and Zentilli (1993) suggested that an additional stratigraphy of 1.5 to $4 \mathrm{~km}$ was present in the Maritimes with commencement of exhumation at $280 \mathrm{Ma}$ (i.e., Lower Permian). Incorporation of such a pressure correction to the fluid inclusion data suggests a maximum temperature of ca. $160-170^{\circ} \mathrm{C}$ for vein formation. We use a mean temperature of $150^{\circ} \mathrm{C}$ for calculations in the following sections.

\section{Gas Chemistry}

Gas analysis were performed at the University of Toronto by C. Bray on several samples each of barite, fluorite and quartz with uniform results. Given that the only phase detecied in the samples was $\mathrm{H}_{2} \mathrm{O}$, the results are not reported. The absence of dissolved gas species (e.g., $\mathrm{CO}_{2}$ ) is noted given that organic species occur in material from Gays River (Kontak 1998) processed in the same laboratory.

\section{STABLE (O, D, S) AND RADIOGENIC (SR) ISOTOPES}

Isotope data have been acquired for two barite-fluoritequartz veins and also from a single quartz-tourmaline vein for comparative purposes (Table 4). Values of $\delta^{34} \mathrm{~S}$ for barite $(n=8)$ range from +10.5 to $+15.4 \%$, with an average of $+13.3 \pm 2.3 \%$, but a maximum variation of $2.7 \%$ occurs for any one locality (Table 4). This average value equates to $\delta^{34} \mathrm{~S}_{\mathrm{H}_{2}} \mathrm{~S}$ of the fluid of $16 \%$ and $-30.5 \%$ at $200^{\circ}$ and $100^{\circ} \mathrm{C}$, respectively, assuming equilibrium fractionation and complete oxidation of reduced sulphur present as sulphide (e.g., pyrite) in a reservoir (calculated using fractionation equations in Ohmoto and Rye 1979). The complete oxidation of sulphide within either the Meguma Terrane granites (e.g., South Mountain Batholith) or Meguma Group rocks (e.g., Kontak and Smith 1989; Kontak 1990; Poulsen et al. 1991; Sangster 1992) will yield limiting $\delta^{34} \mathrm{~S}_{\mathrm{H}_{2} \mathrm{~S}}$ values for the fluid of between $0 \%$ and $-44 \%$ at $200^{\circ}$ to $100^{\circ} \mathrm{C}$, thus precluding these rocks as potential reservoirs for the $S$. However, dissolution of evaporites in the Windsor Group, which are characterized by $\delta^{34} \mathrm{~S}$ of ca. $+15 \%$ on average (Boyle et al. 1976; Akande and Zentilli 1984), would generate a fluid with the appropriate $\delta^{34} \mathrm{~S}$ signature. Note that more complicated disequilibrium models have not been considered for generating appropriate values as it is not possible to independently evaluate such processes. However, the uniform $\delta^{34} \mathrm{~S}$ values of barite from different veins suggests an equilibrium process is more likely.

Quartz $(n=3)$ from three different barite veins has uniform

Table 4. Summary of isotopic data, Kinsac barite-fluorite veins and Musquodoboit Batholith quartz-tourmailne vein

\begin{tabular}{|c|c|c|c|c|c|c|}
\hline Sample & Mineral & ${ }^{18} \mathrm{O}$ & $\mathrm{D}$ & ${ }^{34} \mathrm{~S}$ & ${ }^{87} \mathrm{Sr} /{ }^{86} \mathrm{Sr}$ & Comments \\
\hline KP-96-1A & barite & & -165 & +15.4 & & vein sample \\
\hline KP-96-1 & quartz & +22.3 & & & & vein sample \\
\hline KP-96-1C & barite & & & +12.7 & $0.712066 \pm 0.000012$ & vein sample \\
\hline KP-96-2A & fluorite & & & & & fluorite along fractures in granite \\
\hline KP-96-2B & fluorite & & -123 & & $0.708604 \pm 0.000025$ & fluorite along fractures in granite \\
\hline KP-96-2.1A & barite & & & +17.9 & & fluorite along fractures in granite \\
\hline KP-96-4A & barite & & & +13.1 & & vein sample \\
\hline$K P-96-4 C$ & quartz & +22.0 & -160 & & & vein sample \\
\hline KP-96-5A & barite & & -162 & +10.9 & & vein sample \\
\hline KP-96-5C & barite & & & +12.7 & $0.712071 \pm 0.000013$ & vein sample \\
\hline KP-96-5B.1 & barite & & & +10.5 & & vein sample \\
\hline KP-96-5B.2 & barite & & & +12.9 & & vein sample \\
\hline KP-96-5 & quartz & +21.9 & -155 & & & vein sample \\
\hline KP-96-6B & quartz & +12.2 & -84 & & & pegmatite/vein in Musquodoboit Batholith \\
\hline KP-96-6A & tourmaline & & -96 & & $0.748587 \pm 0.000015$ & pegmatite/vein in Musquodoboit Batholith \\
\hline
\end{tabular}


$\delta^{18} \mathrm{O}$ values of +21.9 to $+22.3 \%$, which equates to $\delta^{18} \mathrm{O}_{\text {water }}$ of $+10 \%$ for a temperatures of $150^{\circ} \mathrm{C}$ (Fig. 10). An analysis of quartz from a quartz-tourmaline vein of probable magmatic origin in the Kinsac Pluton has a $\delta^{18} \mathrm{O}$ value of $+12.2 \%$, which equates to $\delta^{18} \mathrm{O}_{\text {water }}$ of $10 \%$ at $400^{\circ} \mathrm{C}$, similar to data for hightemperature quartz veins of the SMB (Kontak et al. 1991). From Fig. 10 it is apparent that a high-temperature fluid with a $\delta^{18} \mathrm{O}$ of ca. $10 \%$ could evolve to a low-temperature fluid with the appropriate isotopic composition as the fluid that formed the barite veins, assuming that no interaction or exchange with another reservoir occurred, unless it fortuitously had the appropriate $\delta^{18} \mathrm{O}$ value.

Analysis of fluid extracted from barite, quartz and tourmaline (i.e., fluid inclusions) were analyzed for their $\delta \mathrm{D}$ composition and results are given in Table 4. For barite and quartz from the large barite veins uniform $\delta \mathrm{D}$ values of between -155 and $-165 \%$ are indicated. In contrast, fluorite coating the fracture at locality KP-96-2 has a $\delta D$ value of $-123 \%$ and the quartz and tourmaline from the pegmatite (KP-96-6) have similar $\delta \mathrm{D}$ values of $-84 \%$ and $-96 \%$, respectively. Thus, there is a distinction among the occurrence of samples and their apparent $\delta \mathrm{D}$ values.

The $\delta \mathrm{D}$ values are considerably lower than the -27 to $-86 \%$ values reported in Ravenhurst et al. (1989) for fluid extracted from Carboniferous sulphide and sulphate mineralization. As noted by Ravenhurst et al. (1989), such low values may relate to analytical problems if organics are present (e.g., $\mathrm{CH}_{4}$ ), but gas analysis (see above) indicates a lack of any organics. The $\delta \mathrm{D}$ data are also much lower than the $-50 \%$ value reported for present day meteoric water in the Maritimes (Ravenhurst et al. 1989).

The initial $\mathrm{Sr}$ isotopic composition of vein-forming fluids (i.e., ${ }^{87} \mathrm{Sr}^{86} \mathrm{Sr}_{\mathrm{i}}$ ) can be determined by analyzing Sr-rich and $\mathrm{Rb}$ poor minerals, such as barite, fluorite and tourmaline. Two analyses of barite from different veins yielded similar ${ }^{87} \mathrm{Sr} /{ }^{86} \mathrm{Sr}$ values of 0.71206 (Table 4). In contrast, ${ }^{87} \mathrm{Sr} /{ }^{86} \mathrm{Sr}$ for the fracture coating fluorite and tourmaline from the pegmatite (KP-96-6) are 0.70860 and 0.74858 , respectively. The elevated value for the tourmaline is not related to any microinclusions, based on petrographic examination of the separate. Whereas ${ }^{87} \mathrm{Sr} /{ }^{86} \mathrm{Sr}$ for the fluorite is similar to that of the Meguma Terrane granites (e.g., Clarke and Halliday 1980; Clarke et al. 1997), the ${ }^{87} \mathrm{Sr} /{ }^{86} \mathrm{Sr}$ value for the tourmaline is very radiogenic and likely reflects fluid-mediated fractionation of the isotopes, as suggested by Dostal and Chatterjee (1995) for similarly radiogenic samples in the Davis Lake Complex of the SMB.

\section{Discussion}

The formation of the Kinsac barite-fluorite-quartz veins is addressed in light of the data presented above, and specifically the time of vein formation, the nature and origin of the fluids and solutes and the regional setting of formation, with implications for Carboniferous $\mathrm{Ba}-\mathrm{F}-\mathrm{Zn}-\mathrm{Pb}-\mathrm{Cu}-\mathrm{Ag}$ mineralization.

\section{Age of vein mineralization}

The timing of vein formation is constrained by two

\section{Temperature $\left({ }^{\circ} \mathrm{C}\right)$}

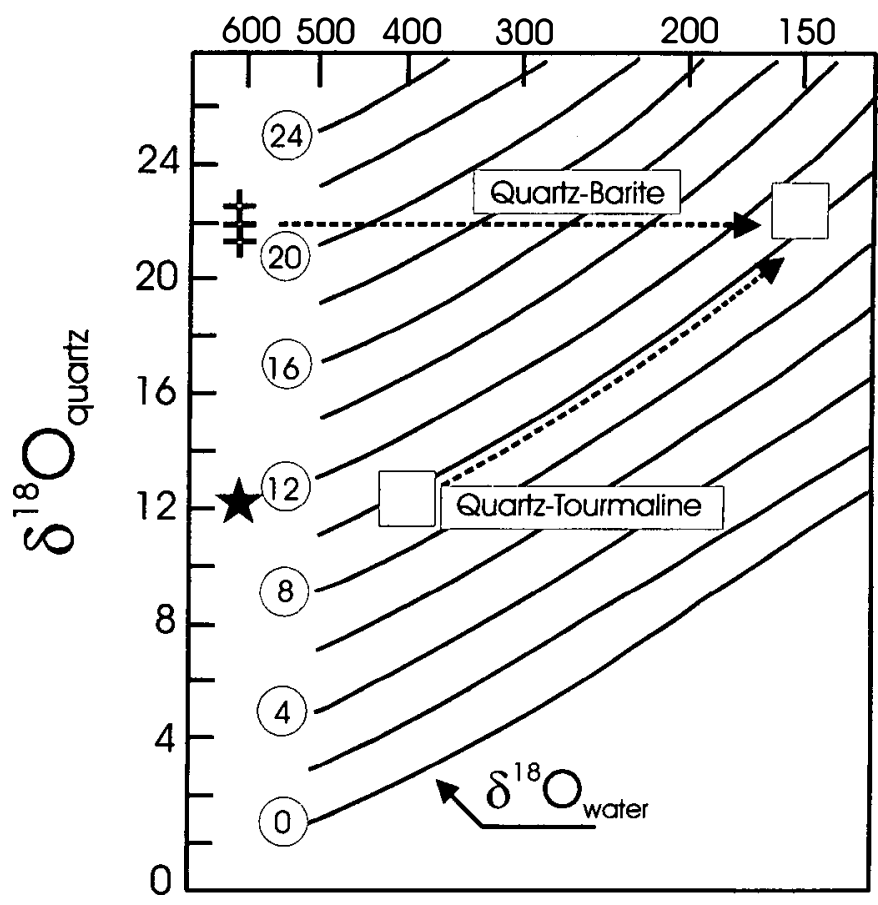

Fig. 10. Plot of $\delta^{18} \mathrm{O}_{\text {quarz }}$ versus Temperature $\left({ }^{\circ} \mathrm{C}\right)$ with isopleths of $\delta^{18} \mathrm{O}_{\text {water, }}$, as calculated using quartz-water fractionation equation of Clayton et al. (1972). Note that a limiting value of $+10 \%$ calculated for $\delta^{18} \mathrm{O}_{\text {water }}$ of the vein is for the temperature range $150^{\circ} \mathrm{C}$. In contrast, the $\delta^{18} \mathrm{O}_{\text {water }}$ value for the quartz-tourmaline vein is calculated for $400^{\circ} \mathrm{C}$.

independent lines of evidence, namely the ${ }^{40} \mathrm{Ar}{ }^{39} \mathrm{Ar}$ age spectrum and ${ }^{34} \mathrm{~S}$ data for barite. In the first case, the $320 \mathrm{Ma}$ step in the age spectrum records a partial resetting due to interaction of the dated sample with hot fluids, which must have approached $150^{\circ} \mathrm{C}$ in order to cause partial outgassing of the feldspar (McDougall and Harrison 1988); these temperatures are consistent with results of the fluid inclusion study. However, given that the first step in the age spectrum has excess argon, the $320 \mathrm{Ma}$ age must be considered as a maximum age, as there may be an unknown component of excess argon in this step. This age is slightly older than the ca. $300 \mathrm{Ma}$ age inferred for mineralization in the basal Windsor Group at, for example, Gays River (Pan et al. 1993; Kontak et al. 1994), but as noted, the $320 \mathrm{Ma}$ date is a maximum age and the $300 \mathrm{Ma}$ age also has associated errors (ca. $\pm 20 \mathrm{Ma}$ ). A thermal event of similar age has been recorded in the partial resetting of argon age spectra at other localities in the central Meguma Terrane, including Gays River (Ravenhurst 1987; Kontak et al. 1994) and West Gore (Kontak et al. 1996), and the western Meguma Terrane (Reynolds et al. 1987; Kontak et al. 1995; Keppie and Dallmeyer 1996). Reynolds et al. (1987) also record disturbed argon age spectra for feldspars in the SMB, but they were unable to distinguish between a Late Carboniferous or Permo-Triassic age for the event based on modelling. The second constraint, which is in fact of indirect nature, comes from the fact that sulphur in the barite must have originated within the Carboniferous evaporites, as discussed above, since there is no other reasonable source reservoir. Thus, vein formation must 
post-date deposition of this Early Carboniferous reservoir. In summary, we consider a maximum age for mineralization to be $320 \mathrm{Ma}$, a date which approximates, within error, the ca. $300 \mathrm{Ma}$ age for $\mathrm{Zn}-\mathrm{Pb}-\mathrm{Ba}-\mathrm{F}$ mineralization in the basal Windsor Group of southern Nova Scotia.

\section{Sources of the vein-forming fluids}

The source(s) of the vein-forming fluids can be addressed by assessing the isotopic ( $\mathrm{S}, \mathrm{O}, \mathrm{Sr}, \mathrm{D})$ and geochemical (REE) data in light of the potential source reservoirs in the Meguma Terrane. We have already addressed these issues and note the following conclusions.

1. Sulphur may have been sourced in the Windsor Group evaporites, as indicated by the above discussion.

2. Oxygen isotopic data indicate the fluid had a $\delta^{18} \mathrm{O}_{\text {water }}$ of $+10 \%$ for a temperature of $\mathrm{ca} .150^{\circ} \mathrm{C}$. This value is similar to the composition inferred for mineralizing fluids at Gays River (Ravenhurst et al. 1987; Savard and Kontak 1998), which are considered to have equilibrated with Horton Group clastic rocks. However, it is not possible to distinguish between a fluid sourced in the Horton clastic rocks and one derived from a cooling granite (Fig. 10), although timing constraints appear to preclude the latter. When combined with the $\delta D$ data (Fig. 11) it is seen that a unique source is not identified and, instead, a mixture of reservoirs is required, with the $\delta \mathrm{D}$ data indicating a possible meteoric component (but see below), and ${ }^{18} \mathrm{O}$ a value consistent with metamorphic or magmatic waters. Formational water would also satisfy the data (see trends for different basins in Fig. 11; Longstaffe 1987). It is also noted that there is a trend in terms of the three types of material sampled, with the quartz-tourmaline data falling just below the magmatic field, as expected given its occurrence, the quartz-barite data falling at the lowest $\delta \mathrm{D}$ values and the fracture-coated fluorite data intermediate.

The $\delta \mathrm{D}$ values for the fluid extracts are abnormally low for an area situated at both low latitude and altitude during the Carboniferous (Whelan 1987), when mineralization is considered to have occurred, and also since this time. Three interpretations of these data are offered. (a) Derivation of a depleted $\delta D$ fluid from extraction of water from diagenetic clay minerals generated within Horton Group sediments during burial, with the clay minerals being depleted by $20 \%$ to $30 \%$ relative to the pore fluid (Kyser 1987). As modelled in Fig. 11, this scenario would require a fluid with initial $\delta D$ of ca. $-130 \%$ to $-140 \%$. (b) Given that the samples used in the study are dominated by secondary inclusions, especially the barite samples, it is possible that the fluids sampled represent post-mineralizing entrapment and do not reflect the mineralizing fluids. Entrapment must have occurred when surficial processes were favourable for generating a fluid with such low $\delta \mathrm{D}$ values. Such a fluid might be generated during periods of low mean temperature (Whelan 1987), such as for example during cooling periods related to glacial stands. (c) Interaction of hydrothermal fluids with organic matter (e.g, graphite, bitumen, petroleum) can result in formation of organic water with depleted $\delta \mathrm{D}$ values compared to the primary signature (Sheppard 1986). Both the Meguma Group basement rocks and the Windsor Group may have provided organic matter for the fluid to interact with and consequently reduce $\delta D$. The last model (c) is preferred to explain the depleted $\delta \mathrm{D}$ values, given the

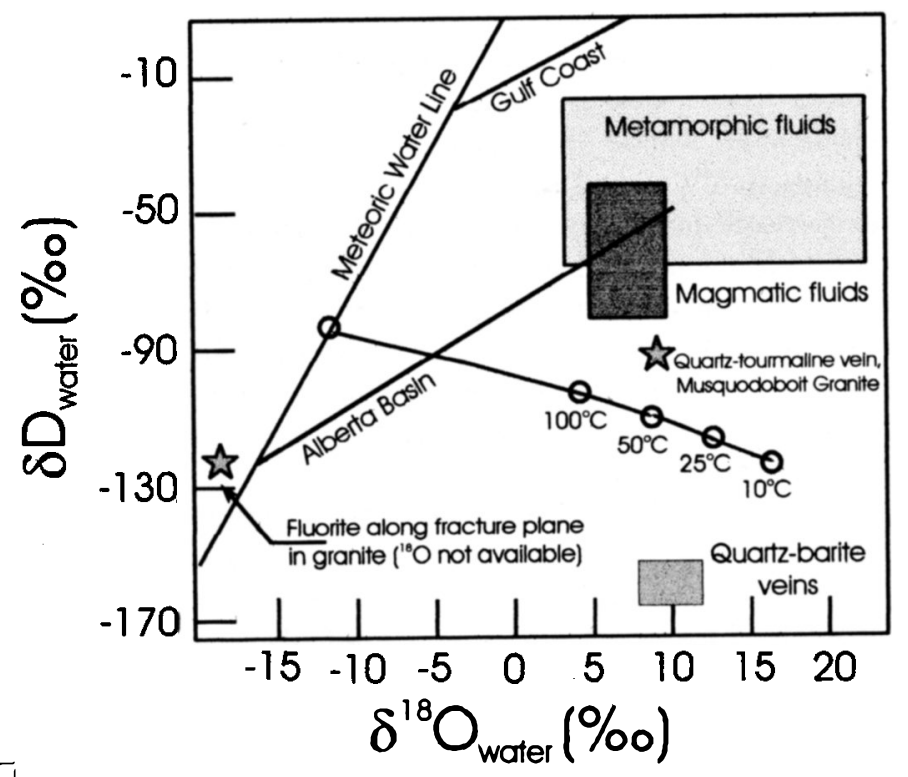

Fig. 11. Plot of $\delta D$ versus $\delta^{18} \mathrm{O}_{\text {water }}$ for quartz-barite vein, fracture coated fluorite and quartz-tourmaline vein material from the Kinsac Pluton. Note that the $\delta^{18} \mathrm{O}_{\text {water }}$ data are calculated from data in Fig. 10 and Table 4 and that the fracture-coated fluorite has no companion $\delta^{18} \mathrm{O}_{\text {water }}$ value. The evolution of water in two sedimentary basins, the Alberta and Gulf Coast, is shown for reference (from Longstaffe 1987). The dots represent the isotopic composition of kaolinite formed at different temperatures from a fluid of the indicated initial composition on the meteoric water line (from Kyser 1987). Note that formation of diagenetic clays in the Horton Group at low temperatures from meteoric water with $\delta \mathrm{D}$ of ca. $-130 \mathrm{l}$ composition could provide a reservoir of appropriate isotopic composition for later remobilization and generation of the fluid that formed the barite veins, as discussed in text.

geological setting during the Carboniferous, which preclude the first interpretation, and the difficulty of evaluating the second model. We also note that recently Kesler et al. (1997) have interpreted similarly depleted $\delta \mathrm{D}$ values (to $-119 \%$ ) for MVT mineralizing brines in the southern Appalachian orogen to reflect interaction of the brines with organic matter in the wallrocks.

3. The uniform $\mathrm{Sr}$ isotopic data for the barite require that the fluid be homogenized or well mixed with respect to ${ }^{87} \mathrm{Sr} /{ }^{86} \mathrm{Sr}$. The fluorite data suggest that this mineral may not have formed from the same fluid as the barite, which is also supported by the REE (see below) and D data (above). The Sr isotope data for the barite are elevated relative to the marine Windsor Group limestones ( $\mathrm{Sr}_{\mathrm{i}}=0.708$; Savard 1996; Ravenhurst et al. 1989) and, instead, suggest a more radiogenic source of Sr. In fact, this observation is similar to that of Ravenhurst et al. (1989) who noted that most base metal, barite and fluorite mineralization hosted by the basal Windsor Group is characterized by a similarly radiogenic ${ }^{87} \mathrm{Sr} /{ }^{86} \mathrm{Sr}$ value (i.e., 0.712 ). Ravenhurst et al. (1989) also suggested that the Sr data indicated interaction of the mineralizing fluids with clastics of the Horton Group, which contains detritus of the Meguma Group. This source has also been proposed by Savard and Kontak (1998) to explain the radiogenic signal $(0.712)$ for ore-stage carbonate at Gays River. We discuss later the significance of the $\mathrm{Sr}$ isotope data for the fracture-coating fluorite and the tourmaline.

4. The REE chemistry of fluorite contrasts markedly with that 
of fluorite from quartz-fluorite veins in the SMB, which are considered to be of magmatic-hydrothermal origin (Muecke and Clarke 1981; Clarke and Chatterjee 1988). We note in particular the lack of a strong negative Eu anomaly that characterizes fluorite from the SMB (Muecke and Clarke 1981 and Fig. 6b), which probably reflects both (a) vein formation at elevated temperatures where $\mathrm{Eu}^{2+}$ dominates (Sverjensky 1984), thus excluding it from the fluorite structure (Clark 1984), and (b) depletion of $\mathrm{Eu}$ in the fluid, because feldspar fractionation within the felsic magma would have reduced significantly the amount of $\mathrm{Eu}$ in the late-stage rocks (e.g., Muecke and Clarke 1981; Kontak et al. 1988; Clarke et al. 1993) which are the progenitors of the fluorite mineralization. The enrichment of $\mathrm{Eu}$ in the Kinsac fluorite, in particular the positive Eu anomaly in one case, would be consistent with low-temperature $\left(\leq 150^{\circ} \mathrm{C}\right)$ oxidizing conditions of formation where signicant activities of both $\mathrm{Eu}^{2+}$ and $\mathrm{Eu}^{3+}$ can occur. Under these conditions, $\mathrm{Ce}^{3+}$ may also be oxidized to $\mathrm{Ce}^{4+}$ and thus partially excluded from the fluorite structure, which would account for the negative $\mathrm{Ce}$ anomaly in the same sample which has the positive Eu anomaly (KP-96-5). An alternative interpretation, that the negative $\mathrm{Ce}$ anomaly has been inherited from the source, is ruled out because such an anomaly does not exist in any of the potential reservoirs (i.e., SMB, Meguma Group rocks, Carboniferous limestone). The fact that the fracture-coating fluorite has negative $\mathrm{Eu}$ and no $\mathrm{Ce}$ anomalies suggests a slightly different fluid chemistry at this locality.

\section{Constraints on intensive parameters of vein formation}

The intensive parameters for vein formation are summarized in Fig. 12, a $\log f \mathrm{O}_{2}$ versus $\mathrm{pH}$ plot modified from Palmer and Williams-Jones (1996) for conditions of $125^{\circ} \mathrm{C}$, with the stability of $\mathrm{Eu}^{2+}$ and $\mathrm{Eu}^{3+}$ from Sverjensky (1984) superimposed. The field for the vein fluids are constrained from the following: (1) trace amounts of calcite in the veins indicate that at times the fluid overlapped the calcite stability field; (2) the presence of late-stage hematite coating fluorite and absence of pyrite; and (3) dominance of trivalent Eu in solution, as discussed above. Based on the foregoing, the field for vein formation is outlined in Fig. 12.

\section{A hydrological and structural model for barite and fuorite mineralization}

The results of this study indicate that vein barite-fluorite mineralization occurred some $50 \mathrm{Ma}$ after emplacement of the host Kinsac granite and is, therefore, related to Early Carboniferous basin formation and tectonics. Given that the maximum inferred age of ca. $320 \mathrm{Ma}$ is close to the ca. $300 \mathrm{Ma}$ age for $\mathrm{Zn}-\mathrm{Pb}-\mathrm{Ba}-\mathrm{F}$ mineralization hosted by basal Windsor Group strata (Ravenhurst et al. 1989; Kontak et al. 1994), we interpret the nature of the Kinsac barite veins in the broader context of Carboniferous metallogeny in southern Nova Scotia. It is suggested that sulphate-bearing fluids generated within the Shubenacadie basin via dissolution of evaporites accessed preexisting structures, depositing barite and fluorite. The salinities of the fluids are just slightly undersaturated in terms of

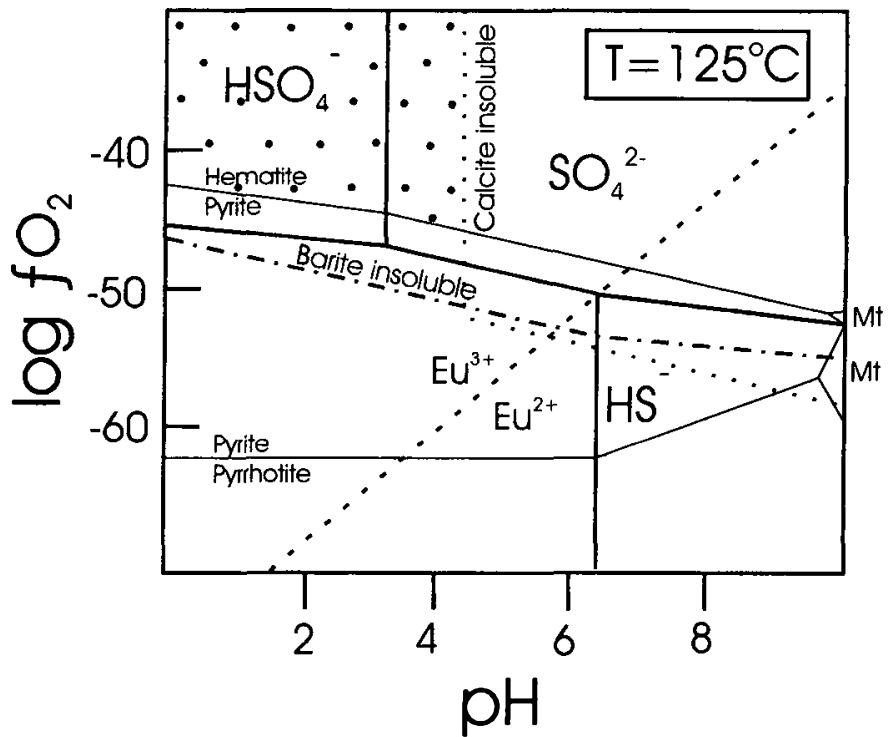

Fig. 12. Plot of $\log f \mathrm{O}_{2}$ versus $\mathrm{pH}$ at $125^{\circ} \mathrm{C}$ showing the mineral stability fields applicable to the Kinsac study (modified from Palmer and Williams-Jones 1996); the stability of $\mathrm{Eu}^{2+}$ and $\mathrm{Eu}^{3+}$ from Sverjensky (1984). The area for barite-quartz-fluorite mineralization from the Kinsac Pluton is indicated by the dotted area. Note that at the temperature and $\log \mathrm{fO}_{2}-\mathrm{pH}$ conditions indicated, $\mathrm{Eu}^{3+}$ is the preferred Eu species in the fluid.

their salinity for the temperatures of formation (Holland and Malinin 1979); which indicates that a single reservoir is responsible for the chemistry of the vein fluid and that this fluid was at one time in equilibrium with salt in the source area. These fluids must also have interacted along the fluid pathway with either the Meguma Group basement or its detrital equivalent, the Horton Group, in order to account for the radiogenic Sr data. The $\mathrm{O}$ isotope data are consistent with this model, whereas the depletion in $\delta \mathrm{D}$ reflects interaction of the fluid with organic matter, either within the Meguma Group or Carboniferous stratigraphy. Deposition of barite is strongly controlled by temperature, but that of fluorite and quartz less so for the temperature range of interest (Holland and Malinin 1979). Thus, the dominance of barite in the veins may reflect the fact that the only intensive parameter to have changed significantly was temperature rather than pressure, $\mathrm{pH}$, or fluid chemistry (e.g., salinity). Temperature change may in part have been due to mixing with a lower temperature, dilute fluid of surficial origin which would explain the small amount of moderate-salinity fluid inclusions (Fig. 8). The lower ${ }^{87} \mathrm{Sr} /{ }^{86} \mathrm{Sr}$ value for the fracturecoating fluorite also suggests that a second fluid may have been involved in formation of some of the fluorite mineralization.

Depth of formation for the veins can be estimated if one assumes that fluid temperature simply reflected the regional geothermal gradient. Thus, for $30^{\circ} \mathrm{C} / \mathrm{km}$ this would equate to 3 $\mathrm{km}$ for lithostatic conditions and more if hydrostatic conditions prevailed, assuming surface conditions of $25^{\circ} \mathrm{C}$. This depth of formation is within the realm of additional cover that Ryan and Zentilli (1993) proposed to the present erosional surface of Maritime Canada, but is considered a maximum as a more elevated geotherm probably existed during the Carboniferous 


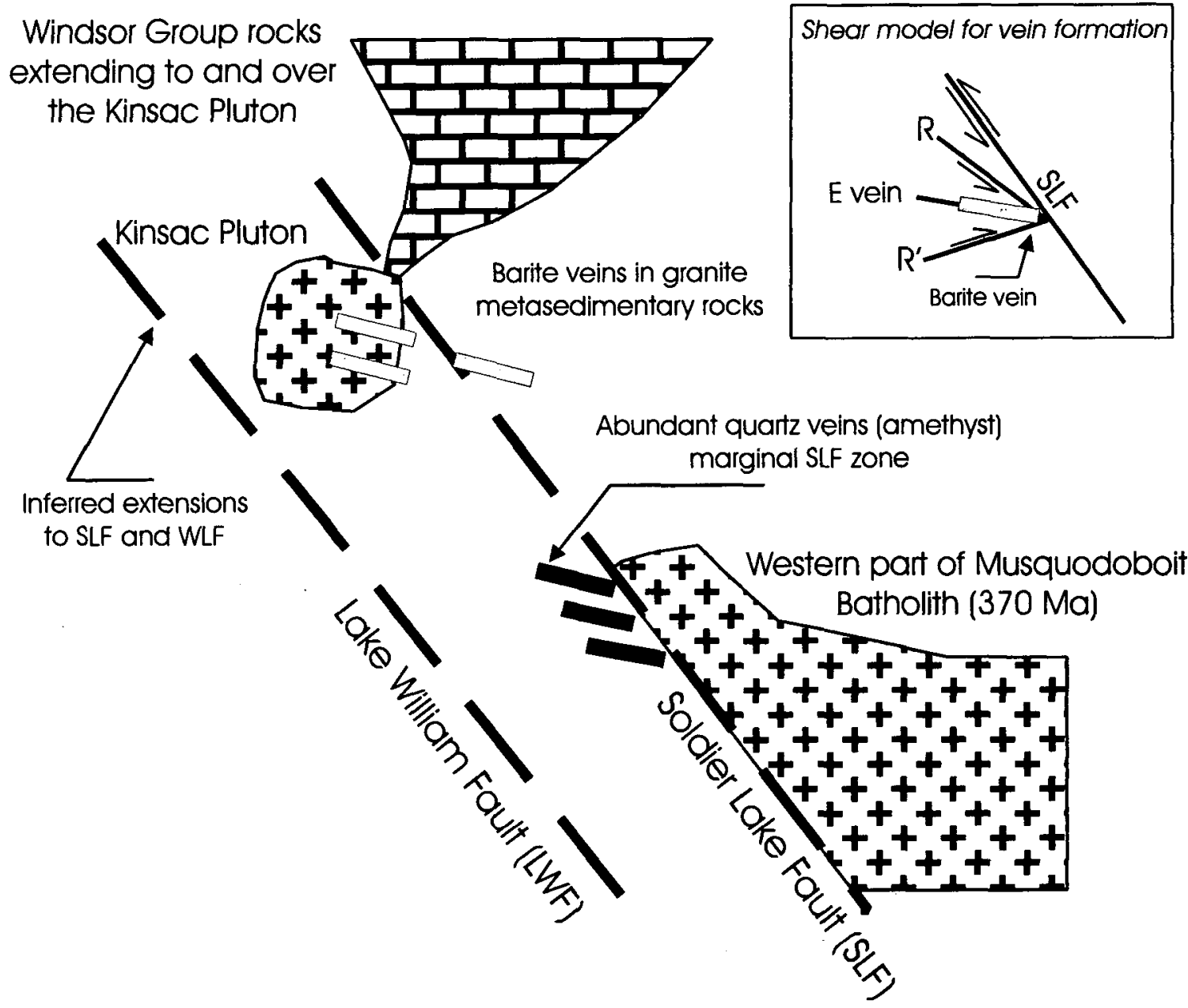

Fig. 13. Schematic diagram relating the occurrence of barite and quartz veins in the Kinsac Pluton and Meguma Group to stresses related to regional faults. Note that the quartz veins occurring along the west side of the Soldier Lake Fault (Horne et al. 1997) have a similar orientation as the barite veins in the Kinsac Pluton. The inset diagram shows that the barite and quartz veins equate to extensional veins with a small shear component in a Riedel shear model, as discussed in the text.

metallogenic event (Chi and Savard 1998). A lower limit of stratigraphic thickness is provided by Giles (1981a), who constrained the cover to ca. $2 \mathrm{~km}$ at the end of Westphalian time. However, the important conclusion is that both these scenarios infer that the Carboniferous strata must have extended from the Shubenacadie Basin over the area of mineralization with a minimum thickness of ca. $2 \mathrm{~km}$, which would equate to a mean pressure-corrected temperature of ca. $150^{\circ} \mathrm{C}$ for the fluid inclusions.

A structural model for formation of the vein structures, presented in Fig. 13, is an attempt to relate veins to regional scale features. However, we reiterate that the barite veins are clearly undeformed and post-dated an episode of intense brittle deformation in the wallrock granite (Fig. $3 \mathrm{~g}, \mathrm{~h}$ ). However, the absence of fibre textures indicates that veins formed within dilatant zones, possibly formed by high fluid pressures. This is not to preclude the fact that the overall regime may have been transtensional, because slickenstriae on the vein-granite contacts indicate that horizontal or strike-slip motion (Fig. 2) occurred prior to vein formation. On a regional scale, barite veins within both the Kinsac Pluton and the Meguma Group (Fletcher Lake showing) and quartz veins proximal to the Soldier Lake Fault
(Horne et al. 1997) have similar orientations and would fit into an extensional shear vein geometry (inset in Fig. 13). Although there is little evidence for sinistral movement along the Soldier Lake Fault, this does not preclude the model as strain can be transferred to the adjacent wallrock. Also, the Lake William Fault has sinistral offset of quartz veins in the Waverly gold district to the north (Faribault 1909). Similar orientations of vein mineralization occur at the West Gore Au-Sb deposit (Kontak et al. 1996) and Dunbrack $\mathrm{Pb}-\mathrm{Zn}-\mathrm{Cu}-\mathrm{Ag}$ occurrence (Kontak 1997), and similar structural models have been suggested to account for orientation of those mineralized veins.

In summary, vein formation is considered to reflect regionalscale stresses active during the Early Carboniferous which either generated or reactivated zones of dilatancy in both the granite and metasedimentary rocks. Veins formed due to extension, probably related to high fluid pressures, from heated brines derived from nearby Carboniferous basins. Given the temperature of vein formation (i.e., $150^{\circ} \mathrm{C}$ ), the fluids must have been in thermal equilibrium with rocks at a depth of a few kilometres, but mixing with surficial waters also occurred. The mineralization can be considered to fit into the broad metallogenetic evolution of the Carboniferous basins of southern 
Nova Scotia.

\section{Implications of Kinsac barite for Carboniferous metallogeny}

The barite mineralization described herein has implications for the Carboniferous metallogeny of the Meguma Terrane in that it suggests a more extensive cover of Windsor Group rocks than the present outcrop pattern indicates. Giles (1981b) made a similar proposal based on the distribution and lithofacies of the Windsor Group and, as noted earlier, Ryan and Zentilli (1993) made a similar suggestion based on fission-track dating and thermal modelling. In the paleogeographic reconstruction of Giles (1981b), the Kinsac area formed a highland with larger land masses to the southeast (Musquodoboit area and east) and northwest (South Mountain area). However, the results of this study, in particular the fluid inclusion data, suggest that Carboniferous strata, including the basal Windsor Group, most certainly overlay the Kinsac Pluton. A digital elevation model map of the area (Fig. 1) reveals a prominent lowland extending towards the Kinsac area that we suggest was infilled with strata of the Carrolls Corner Formation, which includes evaporite that may have been the source of sulphate in the barite veins. Also of significance is the presence of vein barite at the contact of the Carrolls Corner Formation and basement rocks, as discovered in drill core (Fig. 1), and the barite east of Lake Fletcher. Evidently conditions were favourable for barite mineralization over a considerable area.

On a broader scale, the presence of petroleum fluid inclusions in the epithermal-type, breccia-hosted quartz-bariteadularia veins with $\mathrm{Pb}-\mathrm{Zn}-\mathrm{Au}$ mineralization in the Tobeatic Shear Zone of southwestern Nova Scotia (Fig. 1; Corey and Graves 1996; observations of D. Kontak) would be accounted for by a more extensive cover of Windsor Group rocks. Given that there are no appropriate source rocks in this latter area, an extension of the appropriate cover rocks would resolve this dilemma. If such a cover did indeed exist, then occurrences of barite veins within basement rocks could be more extensive than previously considered possible.

\section{ACKNOWLEDGEMENTS}

Field work and laboratory studies by DJK and RJH were financed by the Nova Scotia Department of Natural Resources and the support of management is acknowledged. Laboratories in the Departments of Geological Sciences at Queen's University and the University of Saskatchewan are supported by NSERC grants to personnel at these institutions. Comments on the paper by reviewers and editors of Atlantic Geology are sincerely appreciated, as are conversations with Bob Boehner, Bob Ryan and A.K. Chatterjee regarding the origin of the these veins. This paper is published with the permission of the Director, Nova Scotia Department of Natural Resources.

AKande, S., and Zentilli, M. 1984. Geologic, fluid inclusion and stable isotope studies of the Gays River lead-zinc deposit, Nova Scotia, Canada. Economic Geology, 79, pp. 1187-1211.

BAKSI, A.K., ARCHIBALD, D.A., and FARRAR, E. 1996. Intercalibration of ${ }^{40} \mathrm{Ar}{ }^{39} \mathrm{Ar}$ dating standards. Chemical Geology, 129, pp. 307324.

BOYLE, R.W. 1972. The geology, geochemistry, and origin of the barite, manganese, and lead-zinc-copper-silver deposits of the WaltonCheverie area, Nova Scotia. Geological Survey of Canada, Bulletin $166,180 \mathrm{p}$.

Boyle, R.W., Wanless, R.K., and Stevens, R.D. 1976. Sulphur isotopic investigation of the barite, manganese and lead-zinccopper deposits of the Walton-Cheverie area, Nova Scotia. Economic Geology, 71, pp. 749-762.

BRAY, C.J., and SPOONER, E.T.C. 1992. Fluid inclusion volatile analysis by gas chromatography with photoionization/micro-thermal conductivity detectors: Applications to magmatic $\mathrm{MoS}_{2}$ and other $\mathrm{H}_{2} \mathrm{O}-\mathrm{CO}_{2}$ and $\mathrm{H}_{2} \mathrm{O}-\mathrm{CH}_{4}$ fluids. Geochimica et Cosmochimica Acta, 56, pp. 261-272.

BROWN, P.E. 1989. FLINCOR: A microcomputer program for the reduction and investigation of fluid inclusion data. American Mineralogist, 74, pp. 390-1393.

BROWN, P.E., and LAMB, W.M. 1989. P-V-T properties of fluids in the system $\mathrm{H}_{2} \mathrm{O}-\mathrm{CO}_{2}-\mathrm{NaCl}$ : New graphical presentations and implications for fluid inclusion studies. Geochimica et Cosmochimica Acta, 53, pp. 1209-1221.

CHI, G.-X., and SAVARD, M.M. 1998. Basinal fluid flow models related to $\mathrm{Zn}-\mathrm{Pb}$ mineralization in the southern margin of the Maritimes Basin, eastern Canada. Economic Geology, 93, pp. 896-910.

ClARK, A. 1984. Mineralogy of the rare earth elements. In Developments in Geochemistry: Rare Earth Element Geochemistry. Edited by P. Henderson. Elsevier, New York, pp. 33-62.

Clarke, D.B., and Chatterjee, A.K. 1988. Physical and chemical processes in the South Mountain Batholith. In Recent Advances in the Geology of Granite-Related Mineral Deposits. Edited by R.P. Taylor and D.F. Strong. Canadian Institute of Mining and Metallurgy, Special Volume 39, pp. 223-233.

CLARKE, D.B., and HALLIDAY, A.N. 1980. Strontium isotope geology of the South Mountain Batholith, Nova Scotia. Geochimica et Cosmochimica Acta, 44, pp. 1045-1058.

Clarke, D.B., ReynoldS, P.H., MACDonald, M.A., and LongstafFe, F. 1993. Leucogranites from the eastern part of the South Mountain Batholith, Nova Scotia. Journal of Petrology, 34, pp. $653-679$.

Clarke, D.B., MacDonald, M.A., and Tate, M.C. 1997. Late Devonian mafic-felsic magmatism in the Meguma Zone, Nova Scotia. Geological Society of America, Memoir 191, pp. 107-127.

Clayton, R.N., and Mayeda, T.K. 1963. The use of brominepentafluoride in the extraction of oxygen from oxides and silicates for isotopic analyses. Geochimica et Cosmochimica Acta, 27, pp. 43-52.

Clayton, R.N., ONEIL, J.R., and MAYEDA, T.K. 1972. Oxygen isotope exchange between quartz and water. Journal of Geophysical Research, 77, pp. 3057-3067.

COOLEN, P.R. 1974. The geology of the Kinsac Pluton; Unpublished B.Sc. thesis, Dalhousie University, Halifax, Nova Scotia.

COREY, M.C., and GRAVES, R.M. 1996. Investigation of epithermaltype, breccia-hosted $\mathrm{Pb}-\mathrm{Zn}-\mathrm{Ba}-\mathrm{Au}$ mineralization within the Tobeatic Shear Zone of southwestern Nova Scotia. Nova Scotia Department of Natural Resources, Minerals and Energy Branch, Open File Report 96-008.

CREASER, B. 1996. Interpretation and modelling of gravity data within the Meguma Terrane, central Nova Scotia. Unpublished B.Sc. thesis, Dalhousie University, Halifax, Nova Scotia.

Dalrymple, G.B., AleXander, JR., E.C., LANPHERE, M.A., and KRAKER, G.P. 1981. Irradiation of samples for ${ }^{40} \mathrm{Ar} r^{39} \mathrm{Ar}$ dating using the Geological Survey TRIGA Reactor. U.S. Geological 
Survey, Professional Paper 1176, 55 p.

DOSTAL, J., and ChATTERJEE, A.K. 1995. Origin of topaz-bearing and related peraluminous granites of the Late Devonian Davis Lake pluton, Nova Scotia, Canada: crystal versus fluid fractionation. Chemical Geology, 43, pp. 67-88.

FARIBAULT, E.R. 1909. Waverley Sheet, Map 67, Halifax and Hants Counties; Canada Department of Mines, Geological Survey Branch, Map 1025, scale 1:63 360.

FELDERHOF, G.W. 1978. Barite, celestite and fluorite in Nova Scotia. Nova Scotia Department of Mines, Bulletin No. 4, 463 p.

GILES, P.S. 1981a.The Windsor Group of the Mahone Bay area, Nova Scotia. Nova Scotia Department of Mines and Energy, Paper 81-3, $51 \mathrm{p}$.

GILES, P. 1981b. Major transgressive-regressive cycles in Middle to Late Visean rocks of Nova Scotia. Nova Scotia Department of Mines and Energy, Paper 81-2, $27 \mathrm{p}$.

HENDERSON, P. 1984. General geochemical properties and abundances of the rare earth elements. In Developments in Geochemistry: Rare Earth Element Geochemistry. Edited by P. Henderson. Elsevier, New York, pp. 1-33.

HICKS, R.J., JAMIESON, R.A., and REYNOLDS, P.H. 1999. Detrital and metamorphic ${ }^{40} \mathrm{Ar} /{ }^{39} \mathrm{Ar}$ ages from muscovite and whole-rock samples, Meguma Supergroup, southern Nova Scotia. Canadian Journal of Earth Sciences, 36, pp. 23-32

HOLLAND, H.D., and MALININ, S.D. 1979. The solubility and occurrence of non-ore minerals. In Geochemistry of Hydrothermal Ore Deposits, Edited by H.L. Barnes, John Wiley \& Sons, New York, pp. 461-509.

HORNE, R.J., BAKer, D., FeETHAM, M., and MacDonald, L. 1997. Preliminary geology of the Waverly-Halifax airport area, central Meguma project area. In Nova Scotia Department of Natural Resources, Report of Activities. Edited. by D.R. MacDonald and K.A. Mills. Report 97-1, pp. 57-72.

HORNE, R.J., MACDONALD, M.A., COREY, M.C., and HAM, L.J. 1992. Structure and emplacement of the South Mountain Batholith, southwestern Nova Scotia. Atlantic Geology, 28, pp. 29-50.

HoRne, R.J., MacDonald, L., Bhatnagar, P., and TÉNIĖRe, P. 1998. Preliminary bedrock geology of the Lucasville-Lake Major area, central Meguma mapping project, central Nova Scotia. In Nova Scotia Department of Natural Resources, Report of Activities. Edited. by D.R. MacDonald and K.A. Mills. Report 98-1, pp. 1526.

JENNER, G.A., LONGERICH, H.P., JACKSON, S.E., and FRYER, B.J. 1990. ICP-MS - a powerful tool for high precision trace element analyses in earth sciences: evidence from analysis of selected USGS reference samples. Chemical Geology, 83, pp. 133-148.

KEPPIE, J.D., and DALLMEYER, R.D. 1987. Dating transcurrent terrane accretion: an example from the Meguma and Avalon composite terranes in the northern Appalachians. Tectonics, 6, pp. 831-847.

KEPPIE, J.D., and DALLMEYER, R.D. 1996. Late Paleozoic collision, delamination, short-lived magmatism, and rapid denudation in the Meguma Terrane (Nova Scotia, Canada): constraints ${ }^{40} \mathrm{Ar} /{ }^{39} \mathrm{Ar}$ isotopic data. Canadian Journal of Earth Sciences, 32, pp. 644659.

Kesler, S.E., VennemanN, T.W., Frederickson, C., Breithaupt, A., VAZQUEZ, R., and FURMAN, F.C. 1997. Hydrogen and oxygen isotope evidence for origin of MVT-forming brines, southern Appalachians. Geochimica Cosmochimica Acta, 61, pp. 15131523.

KONTAK, D.J. 1990. A sulphur isotope study of main-stage tin and base metal mineralization at the East Kemptville tin deposit, Yarmouth County, Nova Scotia, Canada: Evidence for magmatic origin of metals and sulphur. Economic Geology, 85, 399-407.

KONTAK, D.J. 1992. A preliminary report on the geological, geochemical, fluid inclusion and isotopic studies of the Gays River
$\mathrm{Zn}-\mathrm{Pb}$ deposit, Nova Scotia. Nova Scotia Department of Natural Resources, Open File Report 92-014, 223 p.

KONTAK, D.J. 1997. Mineralogical and geochemical studies of the Dunbrack $\mathrm{Pb}-\mathrm{Cu}-\mathrm{Zn}-\mathrm{Ag}$ deposit, Musquodoboit Batholith, Nova Scotia. In Nova Scotia Department of Natural Resources, Report of Activities. Edited. by D.R. MacDonald and K.A. Mills. Report 97-1, pp. 73-86.

KONTAK, D.J. 1998. A study of fluid inclusions in ore and gangue mineral phases from a carbonate-hosted $\mathrm{Zn}-\mathrm{Pb}$ deposit, Gays River, Nova Scotia. Economic Geology, 93, pp. 793-817.

KONTAK, D.J., and SMITH, P.K. 1989. Sulphur isotopic composition of sulphides from the Beaver Dam and other Meguma Group-hosted gold deposits, Nova Scotia: implications for genetic models. Canadian Journal of Earth Sciences, 26, pp. 1617-1629.

KONTAK, D.J., and SMITH, P.K. 1993. A metaturbidite-hosted lode gold deposit: The Beaver Dam deposit, Nova Scotia: I. Vein paragenesis and mineral chemistry. Canadian Mineralogist, 31, pp. 471-522.

KONTAK, D.J., STRONG, D.F., and KERRICH, R. 1988. Crystal-melt-fluid phase equilibria versus late-stage fluid-rock interaction in granitoid rocks of the South Mountain Batholith, Nova Scotia: whole rock geochemistry and oxygen isotope evidence. Maritime Sediments and Atlantic Geology, 24, pp. 97-110.

KONTAK, D.J., KERRICH, R., and STRONG, D.F. 1991. The role of fluids in the late-stage evolution of the South Mountain Batholith, Nova Scotia: further geochemical and oxygen isotopic studies. Atlantic Geology, 27, pp. 29-48.

KONTAK, D.J., FARRAR, E., and MCBridE, S.L. $1994 .{ }^{40} \mathrm{Ar} /{ }^{39} \mathrm{Ar}$ dating of fluid migration in a Mississippi Valley-Type deposit: the Gays River $\mathrm{Zn}-\mathrm{Pb}$ deposit, Nova Scotia, Canada. Economic Geology, 89, pp. 1501-1517.

KONTAK, D.J., FARRAR, E., MCBRIDE, S.L., and MARTIN, R.F. 1995. Mineral chemistry and ${ }^{40} \mathrm{Ar} /{ }^{39} \mathrm{Ar}$ dating of muscovite from the East Kemtpville leucogranite, southern Nova Scotia: evidence for localized resetting of ${ }^{40} \mathrm{Ar} /{ }^{39} \mathrm{Ar}$ systematics in a shear zone. Canadian Mineralogist, 33, pp. 1237-1253.

KontaK, D.J., HORNE, D.J., and SMITH, P.K. 1996. Hydrothermal characterization of the West Gore Sb-Au deposit, Meguma Terrane, Nova Scotia, Canada. Economic Geology, 91, pp. 12391262.

KYSER, T.K. 1987. Equilibrium fractionation factors for stable isotopes. In Stable Isotope Geochemistry of Low Temperature Fluids. Edited by T.K Kyser. Mineralogical Association of Canada, Short Course Notes, Vol. 13, pp. 1-84.

LONGSTAFFE, F.J. 1987. Stable isotope studies of diagenetic processes. In Stable Isotope Geochemistry of Low Temperature Fluids. Edited by T.K Kyser.Mineralogical Association of Canada, Short Course Notes, Vol. 13, pp. 187-257.

MACDONALD, A.S. 1999. Lake Ainslie barite-fluorite veins, Cape Breton Island, Nova Scotia; Geological Survey of Canada, Open File Report 3742, 52p.

MCDOUgall, I., and HarRisOn, T.M. 1988. Geochronology and thermochronology by the ${ }^{40} \mathrm{Ar} /{ }^{39} \mathrm{Ar}$ method. New York, Oxford University Press, Oxford Monographs on Geology and Geophysics, No. 9, 212 p.

MUECKE, G.K., and CLARKE, D.B. 1981. Geochemical evolution of the South Mountain Batholith, Nova Scotia: rare-earth-element evidence. Canadian Mineralogist, 19, pp.133-146.

OHMOTO, H., and RYE, R.O. 1979. Isotopes of sulphur and carbon. In Geochemistry of Hydrothermal Ore Deposits. Edited by H.L. Barnes. Wiley Interscience, New York, pp. 509-567.

PalMER, D.A.S., and Williams-JoNES, A. 1996. Genesis of the carbonatite-hosted fluorite deposit at Amba Dongar, India: evidence from fluid inclusions, stable isotopes and whole rockmineral chemistry. Economic Geology, 91, pp. 934-950. 
Pan, H., Symons, D.T.A., and SANGSTER, D.F. 1993. Paleomagnetiwm of the Gays River zinc-lead deposit, Nova Scotia: Pennsylvanian ore genesis. Geophysical Research Letters, 20, pp. 1159-1162.

Poulson, S.R., KuBILIUS, W.P., and OHMOTO, H. 1991. Geochemical behaviour of sulphur in granitoids during intrusion of the South Mountain Batholith, Nova Scotia, Canada. Geochimica et Cosmochimica Acta, 55, 3809-3830.

RAVENHURST, C.E. 1987. An isotopically and thermochronologically constrained model for lead-zinc and barium mineralization related to Carboniferous basin evolution in Nova Scotia, Canada: Unpublished Ph.D. thesis, Dalhousie university, Halifax, Nova Scotia, $247 \mathrm{p}$.

RAVENHURST, C.E., REYNOLDS, P.H., and ZENTILLI, M. 1987. Isotopic constraints on the genesis of $\mathrm{Zn}-\mathrm{Pb}$ mineralization at Gays River, Nova Scotia, Canada. Economic Geology, 82 pp. 1294-1308.

Ravenhurst, C.E., Reynolds, P.H., Zentilli, M., Krueger, H.W., and BLENKINSOP, J. 1989. Formation of Carboniferous $\mathrm{Pb}-\mathrm{Zn}$ and barite mineralization from basin-derived fluids, Nova Scotia, Canada. Economic Geology, 84, pp. 1471-1488.

REYNOLDS, P.H., ZENTILLI, M., and MUECKE, G.K. 1981. K-Ar and ${ }^{40} \mathrm{Ar} /{ }^{39} \mathrm{Ar}$ geochronology of granitoid rocks from southern Nova Scotia: its bearing on the geological evolution of the Meguma Zone of the Appalachians. Canadian Journal of Earth Sciences, 18, pp. 386-394.

Reynolds, P.H., Elias, P., Muecke, G.K. \& Grist, A.M. 1987. Thermal history of the southern Meguma Zone, Nova Scotia, from an ${ }^{40} \mathrm{Ar} /{ }^{39} \mathrm{Ar}$ and fission track dating study of intrusive rocks. Canadian Journal of Earth Sciences, 24, pp. 1952-1965.

ROCK, L., and PAQUETTE, J. 1998. Sector and intrasector zoning of $\mathrm{Sr}$ in barite: Evidence of site-specific kinetics during crystal growth. Geological Association of Canada-Mineralogical Association of Canada, Program with Abstracts, 23, p. A158.

ROEDDER, E. 1984. Fluid inclusions. Reviews in Mineralogy, Mineralogical Society of America, Volume 12, $644 \mathrm{p}$.

RYAN, R.J., and ZENTILLI, M. 1993. Allocyclic and thermochronological constraints on the evolution of the Maritimes Basin of eastern Canada. Atlantic Geology, 29, pp. 187-197.

SANGSTER, A.L. 1992. Light stable isotope evidence for a metamorphic origin for bedding-parallel gold-bearing veins in Cambrian flysch, Meguma Group, Nova Scotia. Exploration and Mining Geology, 1, pp. 69-79.

SAVARD, M.M. 1996. Pre-ore burial dolomitization adjacent to the carbonate-hosted Gays River $\mathrm{Zn}-\mathrm{Pb}$ deposit, Nova Scotia. Canadian Journal of Earth Sciences, 33, pp. 303-315.

SAVARD, M.M., and KONTAK, D.J. 1998. $\delta^{13} \mathrm{C}-\delta^{18} \mathrm{O}-{ }^{87} \mathrm{Sr} /{ }^{86} \mathrm{Sr}$ covariations in ore-stage calcites at and around the Gays River PbZn deposit - Fluid mixing or single brine models? Economic Geology, 93, pp. 818-833.

SHEPPARD, S.M.F. 1986. Characterization and isotopic variations in natural waters. In Stable Isotopes in High Temperature Geological Processes. Edited by J.W. Valley, A.P. Taylor, Jr., and J.R. O'Neil. Mineralogical Society of America Reviews in Mineralogy, 16, pp. 165-184.

STEIGER, R.H., and JAGER, E. 1977. Subcommission on geochronology: Convention on the use of decay constants in geo- and cosmochronology. Earth and Planetary Science Letters, 36, pp. 359-362.

Strong, D.F., FrYER, B.J., and KERRICH, R. 1984. Genesis of the St. Lawrence fluorspar deposits as indicated by fluid inclusion, rare earth element and isotopic data. Economic Geology, 79, pp. 11421158.

SVERJENSKY, D.A. 1984. Europium redox equilibria in aqueous solution. Earth and Planetary Science Letters, 67, pp. 70-78.

WHELAN, J.A. 1987. Stable isotope hydrology. In Stable Isotope Geochemistry of Low Temperature Fluids. Edited by T.K Kyser. Mineralogical Association of Canada, Short Course Notes, Vol. 13, pp. 129-161. 